Environment, Biodiversity \& Soil Security
(EBSS)
http://jenvbs.journals.ekb.eg//

\title{
Oil Yield and Nutrients Uptake by Irradiated Canola (Brassica napus L.) in Response to Different Nitrogen and Irrigation Water Sources
}

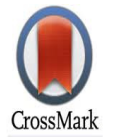

\author{
Hassan H. Abbas ${ }^{1}$, Soliman M. Soliman², Ihab M. Farid ${ }^{1}$, Yahia G.M. Galal2 ${ }^{2}$, \\ Mohamed H.H. Abbas ${ }^{1 *}$, Ibarhim Mohamed ${ }^{1}$, Ahmed A. Moursy ${ }^{2}$ and Sami H. \\ Moslhy ${ }^{2}$ \\ ${ }^{1}$ Soils and Water Department, Faculty of Agriculture, Benha University, Egypt. \\ ${ }^{2}$ Atomic Energy Authority, Nuclear Research Center, Soil and Water Research \\ Department, Abu-Zaabl, 13759, Egypt.
}

\begin{abstract}
$\mathbf{A}^{1}$
FIELD experiment was conducted at the Experimental Farm of Soil and Water Research Department, Nuclear Research Centre, Atomic Energy Authority, Inshas, Egypt to investigate the effects of radiating canola seeds with Y-ray at three doses, i.e. 100, 200 and 300 Gy vs the non-irradiated controlon plant growth performance and yield productivity. Nitrogen fertilization and the source of irrigation water were also matters of concern in this study. All experimental plots received the recommended dose of $\mathrm{N}$-fertilizers $\left(150 \mathrm{~kg} \mathrm{~N} \mathrm{ha}^{-1}\right)$ in either of the following forms: $100 \%$ mineral-N, $100 \%$ organic-N or $50 \%$ mineral- $\mathrm{N}+50 \%$ organic- $\mathrm{N}$. Also, a drip irrigation-system was constructed to irrigate canola plants with either fresh-water or treated-wastewater. Irradiation, in general, resulted in higher values of canola-dry-weights which were enhanced by increasing gamma ray dose up to 300Gy. Similarly, NPK contents within different plant parts of the irradiated-canola increased in an order coincide with the magnitudes of the used irradiation dose, i.e. 300Gy $>200 \mathrm{~Gy}>100 \mathrm{~Gy}>0 \mathrm{~Gy}$. Moreover, oil yield was significantly increased with increasing gamma dose. On the other hand, the enhancement of NPK uptake was more vigorous in case of combined-fertilization-treatment $(50 \%$ mineral- $\mathrm{N}+50 \%$ organic- $\mathrm{N})$ than the application of either $100 \%$ mineral- $\mathrm{N}$ or $100 \%$ organic-N. This consequently raised significantly root and shoot dry weights as well as seed yield and canola oil productivity. It seems that irrigation with treated wastewater resulted in higher increases in NPK uptake as well as canola oil yield than irrigation with fresh-water. Thus, it can be deduced that the combined-fertilization-treatment and high irradiation dose of gamma-ray had achieved the highest increases in plant DW and productivity (5.3 $\mathrm{Mg}$ seed yield $\mathrm{ha}^{-1}$ ), at the same time these values were higher under irrigation with treated wastewater than those irrigated with fresh water.
\end{abstract}

Keywords: Canola, Compost, Chemical N-fertilizer, Gamma ray, Nutrients, Oil yield, Sandy soil.

\section{Introduction}

Canola (Brassica napus L.) is an important oil crop, ranking third after soybean and palm oil in global production (Muhammad et al., 2007). It is also used as a biodiesel, lubricant, and feed (Wo $\square$ niak et al., 2019). Its name is derived from the two words "Canada" (origin country) and "oleo" (oil) (Canola Council, 2017). The cultivated area of this crop has been globally increased steadily in the last few years as a rotation alternative with cereals and other crops (FAOSTAT, 2013). The world production of

*Corresponding author: Mohamed.abbas@fagr.bu.edu.eg

"galalyehia@yahoo.com

Received: $15 / 06 / 2020$; Accepted: 5/08/ 2020

DOI: $10.21608 /$ jenvbs.2020.32736.1099

C2020 National Information and Documentation Center (NIDOC) 
canola is estimated by approximately 68.20 million mega-grams in 2019/2020 (USDA, 2020) with an average production yield reached 5.717 $\mathrm{Mgha}^{-1}$ (Djaman et al. 2018). In Egypt, canola is grown as a winter oil seed plant (Elshazly et al. 2019) with a relatively low yield productivity, ranging approximately from 1.9 Mgha $^{-1}$ (Hozayn and El-Mahdy, 2017)to 3.145 $\mathrm{Mg} \mathrm{ha}^{-1}$ (Kheir and Kamara, 2019). In order to raise canola productivity in soils of Egypt, the following protocols should be taken into account (1) improving the nutritional status of the grown plants and (2) inducing further positive physiological changes in plants to take up more soil nutrients.

The traditional approach to raise soil productivity is through amending soils with synthetic fertilizers (Verma et al., 2020); however, in light textured ones, considerable losses of the applied nutrients may occur through water leachate (Elshony et al., 2018). Moreover, the prices of synthetics fertilizers are growing up continuously (Rouhollahi et al., 2020) and this may threaten the sustainability of growing plants in Egypt. Accordingly, substituting chemical synthetic fertilizers partially with slow-releaseorganic fertilizers should come to light to sustain development (El-Akhdar et al., 2018 and Tang et al. 2019). Such a"Green Revolution" may change the country category from food importer to selfsufficient (Verma et al., 2020).

Canola crop is very responsive to $\mathrm{N}$ (Lewis et al., 1987; Jackson, 2000 and Šidlauskas \& Tarakanovas, 2004). Its requirements for $\mathrm{N}$ fertilizers vary a lot depending on soil type, climate, management practices, timing of $\mathrm{N}$ application, crop cultivars etc. (Ali et al., 1998); consequently N-fertilization affects significantly crop yield quantity and quality (Rathke et al. , 2005). Moreover, it has positive impacts on plant height, number of branches per plant, number of pods per plant, seed yield and oil content (Ahmadi and Bahrani, 2009). It seems that synthetic $\mathrm{N}$-fertilizers can effectively fulfill plant needs for $\mathrm{N}$ and; therefore, increase crop productivity (Vaillancourt et al., 2018). However, its extensive use may pollute the environment (Chai et al., 2019 and Shahzad and Ahmad, 2019), besides being of relative low N-use efficiency (Zhang et al., 2020), which counts only to $33 \%$ of the applied nitrogen in harvestable yields (Shahzad and Ahmad, 2019). Thus, managing $\mathrm{N}$-inputs is necessary to sustain the environment ( $\mathrm{Yu}$ et al.
2019 and Zhang et al. 2020). In this concern, organic amendments canpartially satisfy plant needs for N, i.e. canola (Kazemeini et al., 2008). Application of compost to agricultural lands has become a common practice especially in soils which have been depleted of organic matter as a consequence of continuous cropping (Farid et al. 2014 and Elshony et al., 2019). In comparison to chemical fertilizers, compost is considered a slow release source of soil nutrients e.g., nitrogen, phosphorus, and potassium; and; therefore this organic amendment can supply soils with nutrients continuously and steadily (Carter et al., 2004) without recording negative ecological impacts (Farid et al., 2018). Furthermore, addition of compost improves soil fertility by increasing both the quantity and the quality of soil organic matter (Rivero et al., 2004), and also increases soil water holding capacity, especially in light textured ones (Farid et al., 2014).

Shortage in quantity of irrigation water demand is a limiting factor affecting negatively crop productivity in many arid zone soils including the arable lands of Egypt (AbdAllah et al., 2019; Aboelsoud and Ahmed, 2020 and Farid et al., 2020b). This; consequently, lead us to use other unconventional water resources like wastewater (Abbas and Bassouny, 2018; Abbas et al. 2020; Bassouny and Abbas. 2020; Bassouny et al. 2020; Elcossy et al. 2020 and Farid et al. 2020a) which became a necessity (Galaviet al., 2010). Treated wastewater is widely recognized as a reliable water source. During the last two decades, the reuse of treated wastewater for agricultural irrigation has expanded, especially in arid and semi-arid regions, helping to relieve water scarcity and improving the means for local food production (Blumenthal et al., 2000; Ali et al., 2016 and Ibrahim et al., 2016). The use of domestic wastewater for irrigation is advantageous for many reasons including water conservation, ease of disposal, nutrient utilization, and avoidance of surface water pollution. Nevertheless, it must be keep in mind that although the soil is an excellent adsorbent for most soluble pollutants, domestic wastewater must be treated before it can be used for crop irrigation to prevent the potential risk to both human and the environment (Mohammed, 2006). In the current study, the output of El-Gabal ElAsfar wastewater treating plant (WWTP) is taken into account as a source of irrigation water. This plant is probably the largest WWTP in Egypt. Its capacity is estimated by $2.0 \mathrm{Mm}^{3}$ /day (ABD, 
2009). Its outlet undergoes secondary treatment and is actually in use for irrigating fruits (Drechsel and Hanjra, 2018). It is worthy to mention that using treated wastewater for irrigating plants may increase plant growth beyond those attained for irrigation with fresh Nile water (Galal et al., 2018). Moreover, the combination between organic matter application and irrigation with treated wastewater might bring further positive impacts on soil productivity (Hameeda et al., 2019). The thirds approach to increase canola productivity is through inducing further positive plant physiological changes by treating seeds with $\mathrm{Y}$-rays prior to their cultivation (Majeed et al., 2017; Ariraman et al., 2018 and Kumar et al., 2019). Gamma irradiation is one of the effective techniques that can be used to increase canola yield and quality, especially under biotic/ abiotic stresses (Akandeh et al., 2017). Probably, irradiation stimulates seed germination, through production of free radicals in cells (Yildiz, 2018). Moreover, it increases plant drought tolerance through increasing the activities of several antioxidant enzymes (Sen et al., 2017). It also increases the capability of the grown plants to take up more nutrients from treated irrigation water and; hence, increases their productivity (Abbas et al., 2015 and Galal et al., 2018).

The current study aims at evaluating the productivity of canola plants grown on a poor fertile sandy soil, as well as their nutrient acquisition and oil productivity in response

TABLE 1. Chemical properties of the experimental soil to gamma irradiation of seeds, irrigation with treated wastewater and the source of nitrogen fertilization. We believe that the combinations among these three factors are necessary for a significant rise in canola productivity levels.

\section{Materials and Methods}

\section{Materials of study}

A field experiment was carried out at the experimental farm of Soils and Water Research Department, Nuclear Research Centre, Atomic Energy Authority, Egypt. The latitude and longitude of the experimental site are $30^{\circ} 24^{\wedge} \mathrm{N}$ and $31^{\circ} 35^{\circ} \mathrm{E}$, respectively, while the altitude is $20 \mathrm{~m}$ above the sea level. Surface soil samples (0$30 \mathrm{~cm}$ ) were collected prior to canola cropping. These samples were analyzed for their chemical and physical characteristics according to Carter and Gregreich (2008) and results are presented in Table 1.

Compost was obtained from the Nuclear Research Centre, Egyptian Atomic Energy Authority, and analyzed for its chemical and physical characteristics (Table 2).

Seeds of canola (Brassica napus L.) were provided by the research team of Plant Research Department, Nuclear Research Centre, Atomic Energy Authority,Inshas. Treated wastewater was collected from El-Gabal El-Asfar outlet irrigation stream. Chemical characteristics of the used waters were determined according to standard methods outlined by Carter and Gregoric (2008) and results are presented in Table 3.

\begin{tabular}{|c|c|c|c|c|c|c|c|c|c|c|c|}
\hline \multirow{2}{*}{ Parameter } & \multirow{2}{*}{$\begin{array}{c}\text { pH } \\
(1: 2.5)\end{array}$} & \multirow{2}{*}{$\underset{\left(\mathbf{d S} \mathrm{m}^{-1}\right)}{\mathbf{E C}}$} & \multirow{2}{*}{$\begin{array}{l}\mathrm{CaCO}_{3} \\
\left(\mathrm{~g} \mathrm{~kg}^{-1}\right)\end{array}$} & \multirow{2}{*}{$\underset{\left(\mathrm{g} \mathrm{kg}^{-1}\right)}{\mathbf{O M}}$} & \multicolumn{3}{|c|}{$\begin{array}{c}\text { Particle size distribution } \\
(\%)\end{array}$} & \multirow{2}{*}{$\begin{array}{l}\text { Textural } \\
\text { class }\end{array}$} & \multicolumn{3}{|c|}{ Total nutrients, $\mathrm{mg} \mathrm{kg}^{-1}$} \\
\hline & & & & & Sand & Silt & Clay & & $\mathbf{N}$ & $\mathbf{P}$ & $\mathbf{K}$ \\
\hline Value & 7.33 & 1.67 & 0.00 & 0.6 & 92.4 & 4.6 & 3.0 & Sand & 21.30 & 0.6 & 0.20 \\
\hline \multirow{2}{*}{ Parameter } & \multicolumn{4}{|c|}{ Soluble cations $\left(\mathrm{mmol}_{\mathrm{c}} \mathbf{L}^{-1}\right)$} & \multicolumn{4}{|c|}{ Soluble anions $\left(\operatorname{mmol}_{c} \mathbf{L}^{-1}\right)$} & \multicolumn{3}{|c|}{$\begin{array}{c}\text { Available nutrients, } \\
\text { mg kg }^{-1}\end{array}$} \\
\hline & $\mathbf{N a}^{+}$ & $\mathbf{K}^{+}$ & $\mathrm{Ca}^{2+}$ & $\mathbf{M g}^{2+}$ & $\mathrm{CO}_{3}{ }^{2-}$ & $\mathrm{HCO}_{3}^{-}$ & $\mathrm{Cl}^{-}$ & $\mathrm{SO}_{4}{ }^{2-}$ & $\mathbf{N}$ & $\mathbf{P}$ & $\mathbf{K}$ \\
\hline Value & 1.8 & 3.6 & 3.8 & 7.5 & 0.0 & 4.7 & 5.8 & 6.2 & 3.9 & 0.2 & 0.10 \\
\hline
\end{tabular}

Note: $\mathrm{pH}$ was determined in 1:2.5 soil:water suspension, $\mathrm{EC}$ was determined in soil paste extract. Extractants for available nutrients: $\mathrm{KCl}$ for $\mathrm{N}, \mathrm{Na}_{2} \mathrm{CO}_{3}$ (olsen) for P, $\mathrm{NH}_{4}-\mathrm{AOc}$ for $\mathrm{K}$, DTPA for Fe, $\mathrm{Mn}, \mathrm{Zn}$ and $\mathrm{Cu}$, SP: Saturation percent.

TABLE 2. Properties of the compost used in the study

\begin{tabular}{|c|c|c|c|c|c|c|c|c|c|}
\hline \multicolumn{3}{|c|}{ Total nutrients, mg kg $^{-1}$} & \multirow{2}{*}{$\begin{array}{c}\text { Moisture } \\
(\%)\end{array}$} & \multirow{2}{*}{$\begin{array}{l}\mathrm{C} / \mathrm{N} \\
\text { Ratio }\end{array}$} & \multirow{2}{*}{$\begin{array}{c}\text { Organic } \\
\text { carbon }\end{array}$} & \multirow{2}{*}{ Ash } & \multirow{2}{*}{$\begin{array}{c}\text { Organic } \\
\text { matter }\end{array}$} & \multirow{2}{*}{$\begin{array}{c}\mathrm{EC} \\
(1: 2.5) \\
\left(\mathrm{dS} \mathrm{m}^{-1}\right)\end{array}$} & \multirow{2}{*}{$\begin{array}{c}\text { pH } \\
(1: 2.5)\end{array}$} \\
\hline $\mathbf{K}$ & $\mathbf{P}$ & $\mathbf{N}$ & & & & & & & \\
\hline 21.1 & 10.3 & 37.0 & 20.53 & $15.1: 1$ & 207.0 & 643.0 & 356.4 & 2.50 & 7.85 \\
\hline
\end{tabular}


TABLE 3. Characteristics of the treated wastewater and The Nile fresh water used in canola irrigation

\begin{tabular}{ccc}
\hline Property & Fresh water & Treated wastewater \\
\hline $\mathrm{EC}\left(\mathrm{dSm}^{-1}\right)$ & 0.89 & 1.49 \\
$\mathrm{pH}$ & 7.33 & 7.85 \\
$\mathrm{BOD} \mathrm{mgL}{ }^{-1}$ & 3.5 & 60.00 \\
$\mathrm{COD} \mathrm{mg} \mathrm{L}$ & 13 & 80.00 \\
& Soluble anions $\left(\mathbf{m m o l}_{\mathbf{c}} \mathbf{L}^{-1}\right)$ & \\
$\mathrm{SO}_{4}{ }^{2-}$ & 1.19 & 3.33 \\
$\mathrm{CO}_{3}^{2-}$ & 0.00 & 0.05 \\
$\mathrm{HCO}_{3}^{-}$ & 3.05 & 4.06 \\
$\mathrm{Cl}^{-}$ & 3.86 & 7.46 \\
& 2.82 & \\
$\mathrm{~K}^{+}$ & 1.39 & 4.06 \\
$\mathrm{Na}^{+}$ & 2.70 & 3.28 \\
$\mathrm{Ca}^{2+}$ & 1.19 & 4.17 \\
$\mathrm{Mg}^{2+}$ & Soluble cations $\left(\mathbf{m m o l}_{\mathbf{c}} \mathbf{L}^{-1}\right)$ & 3.39 \\
$\mathrm{P}^{-1}$ & 0.02 & 4.02 \\
$\mathrm{NH}_{4}^{-\mathrm{N}}$ & 0.01 & 11.70 \\
$\mathrm{NO}_{3}-\mathrm{N}$ & 0.01 & 2.10 \\
\hline
\end{tabular}

\section{Methods of Study}

Irradiation with gamma ray

Seeds of canola were irradiated in ${ }^{60} \mathrm{Co}$ Gamma Irradiation Unit, at the Nuclear Research Center (NRC), Egyptian Atomic Energy Authority (EAEA). The irradiation facility used was Russian Gamma Cell, Co-60 (Russian, CM20 ), delivered a dose rate of $0.823 \mathrm{kGy} /$ hat the time of experimental research. The irradiation doses were 100, 200 and 300. Un-irradiated seeds for both plants were used as controls. The nonirradiated and irradiated samples were sown after irradiated immediately.

\section{Experimental Layout}

Canola seeds were cultivated on a sandy soil whose properties are listed in Table 2. The experimental design was a split-plot one, where two irrigation treatments (treated wastewater vs Fresh Nile water) were located in main plots while three fertilization treatments (mineral vs organic) were placed in the sub-plots. The radiation treatments (seeds irradiated with gamma ray at either 0 (R0), 100 (R1), 200 (R2) or 300 Gy (R3)) were applied to sub- subplots. The area of each sub-subplots was $10 \mathrm{~m}^{2}$ and all treatments were conducted in triplicates (for more details see Table 4).

All sub- subplots received $\mathrm{P}$ and $\mathrm{K}$ fertilizers during soil preparation at the recommended rates i.e. 110 and $110 \mathrm{~kg} \mathrm{ha}^{-1}$ in the forms of calcium superphosphate and potassium sulphate fertilizers, respectively. In case of $\mathrm{N}$ fertilization, all plants received $150 \mathrm{~kg} \mathrm{ha}^{-1}$ in one of the following forms: 100\% organic-N (compost, F1), $100 \%$ mineral-N (ammonium sulphate, F2), 50\% organic- $\mathrm{N}+50 \%$ mineral-N $(50 \%$ ammonium sulphate $+50 \%$ organic-N, F3). In this concern, compost was added during soil preparation, while the ammonium sulphate fertilizer was added at three equal doses, i.e. during seed cultivation, 30 days and 51 days after seed planting. Canola plants were irrigated with either fresh Nile water or treated wastewater every 21 days using a drip irrigation system. After 140 days from cultivation, plants were harvested from each sub-subplot and the different plant parts were estimated.

\section{Soil and plant analysis}

Collected plant materials were oven dried at $70^{\circ} \mathrm{C}$, for $48 \mathrm{hr}$, then ground and digested using a mixture of $\mathrm{H}_{2} \mathrm{SO}_{4}$ and $\mathrm{H}_{2} \mathrm{O}_{2}$ according to Estefan et al. (2013). Total $\mathrm{N}$ in the plant digests was determined using micro Kjekdahel apparatus. Total $\mathrm{P}$ and $\mathrm{K}$ were estimated in plant digests using. Spectrophotometer (model: Bk-F93, China) and flame photometer (model: PFP7/C), respectively. 
TABLE 4. Details regarding radiation, fertilization and irrigation treatments (total 24 treatments)

\begin{tabular}{lccrrr}
\hline \multicolumn{2}{l}{ Radiation treatment } & & Fertilization treatment & \multicolumn{2}{c}{ Irrigation treatment } \\
\hline R0 & 0 & F1 & $100 \%$ organic-N & W1 & Fresh water \\
R1 & 100 Gy & F2 & $100 \%$ mineral-N & W2 & wastewater \\
R2 & 200 Gy & F3 & $50 \%$ organic-N $+50 \%$ mineral-N & & \\
R3 & 300 Gy & & & & \\
\hline
\end{tabular}

\section{Oil extraction}

Oil extraction took place according to the method described by Akbar et al. (2009) with a slight modification, i.e. seed kernels (3 g sampled from each treatment) were ground using a mechanical method and defatted in a soxhlet apparatus. The extraction was carried out by using hexane. This process continued for $6 \mathrm{hr}$. Solvent was removed by vacuum evaporation and exposed to heat in a drying oven at $50^{\circ} \mathrm{C}$. The amount of oil recovered was calculated as a percentage of total oil present in seeds kernels. Each extraction was run in triplicate and the final value is the average of all.

\section{Oil yield}

The chemical oil extraction implemented in this work was then- hexane oil extraction through a Soxhelt apparatus (or Soxhelt extraction) according to Kyari (2008). Oil yield was calculated on the basis of oil content and grain yield using the formula :

Oil Yield $=$ Seed yield $\times$ oil percentage.

\section{Statistical analysis}

All the obtained data were subjected to ANOVA statistical analysis at LSD 0.05 levels using SPSS (ver. 22) statistical software.

\section{Results and Discussion}

\section{Roots, shoots and seed yields}

Table 5 and Fig. 1 indicate that seed irradiation increased significantly the dry weights of canola root and shoot as well as the total seed yield. Such increases were noticeable with increasing the irradiation dose. Relatively, increases in root DW owing to seed irradiation were about $5 \%, 8 \%$ and $12 \%$ for R1, R2 and R3, respectively. Similar trends, but to somewhat higher extents, were noticed in plants irrigated with treated wastewater. Rahimi and Bahrani (2011) also reported an increase in seed yield of
Brassica napus in response to gamma irradiation by $5 \%$ higher than the non-irradiated control; however, the high doses of gamma irradiation exerted a harmful effect on plant growth and seed yield productivity. Probably, irradiation increased seed germination rate (Yildiz, 2018). Moreover, it increased photosynthetic pigments content (Hamideldin and Eliwa, 2015). Accordingly, the growth of irradiated plants increased, particularly root growth which may, in turn, increase nutrients uptake by plants, e.g. N.

The form of $\mathrm{N}$-fertilization also recorded an effective role in increasing root shoot and seed weights. In this concern, $100 \%$ organic-N (compost, F1) seemed to be more efficient treatment in increasing the above-mentioned growth parameters as well as the seed yield than the mineral $\mathrm{N}$-fertilizer ( $100 \%$ mineral-N, F2) did. In spite of that, the combination between these two sources $(50 \%$ mineral- $\mathrm{N}+50 \%$ organic- $\mathrm{N}$, F3) recorded the highest increases in the weights of canola roots (DW), shoots (DW) and seed yield. This holds true under all irradiation doses. This is because compost was rich in nutrients (Abdelhafez et al. 2016; Farid et al. 2018) and plant growth hormones (Ravindran et al. 2016). Moreover, compost improved soil physical characteristics and fertility (Farid et al. 2014). Accordingly, compost application, either solely or in combination with ammonium sulphate, increased significantly canola growth and seed yield.

A relative increase in root DW of plants was detected in plants irrigated with treated wastewater by about $19 \%$ over those irrigated with fresh water. Similar trends with different extents were noticed with shoots DW and seed yield. Such increases may be related to the relatively high concentrations of plant nutrients and organic matter in wastewater (Guo et al., 2002; Egiarte et al., 2005; Larchevêque et al. , 2006; Lopez et al., 2006 and Ali et al., 2016). 
Interactions among the three studied factors were also of significant effect on canola growth parameters and total seed yield. Generally, the combined fertilizer treatment and high irradiation dose had achieved the highest values of plant DW as well as the seed yield and at the same time these values were more effective under irrigation with treated wastewater than under those irrigated with fresh water. It is worthy to mention that the values of root DW, shoot DW and seed yields owing to seed irradiation with $300 \mathrm{~Gy}$ in presence of " $50 \%$ organic- $\mathrm{N}+50 \%$ mineral -N" and irrigation with treated wastewater were 1.4, 1.5 and 2.4 folds, respectively higher the corresponding ones achieved due to the reference treatment (non-irradiated seeds grown on a soil received 100\% inorganic $\mathrm{N}$ and irrigated with fresh Nile water). This indicates that the response of seed yield towards this combined treatment seemed to be higher than the vegetative growth. Moreover, the obtained seed yield values seemed to be higher than the average yield productivity in Egypt.

\section{Nitrogen uptake}

Seed irradiation raised significantly $\mathrm{N}$-uptake by plants (Table 6 and Fig 2). Such increases were detected under different irradiation doses; however, still higher in case of R3 (300 Gy) than the other doses. In this respect, the mean values of $\mathrm{N}$-uptake by roots indicated that $\mathrm{R} 1$, $\mathrm{R} 2$ and $\mathrm{R} 3$ increased $\mathrm{N}$ uptake by roots by about $42 \%, 80 \%$ and $103 \%$ over R0, respectively. Likewise, canola roots acquainted more nitrogen when fertilized with combined treatment (F3) as compared to either F1 or F2 ones. Similar trends, but somewhat to higher extents, were noticed in plants irrigated with wastewater. These results agree with Anwar et al. (2015), who found that $\mathrm{Y}$-irradiated is a safe and successful method to improve the nutritional value of canola seeds as well as the functional properties of its proteins. This might occur because of the significant increases that took place in plant roots owing to seed irradiation; consequently, N-uptake increased during the early stages (Bouchet et al. 2016). In this concern, canola is a valuable nutrient catch crop during autumn (Rossato et al. 2001). Thus, total N-uptake increased significantly in straw and seeds (Gan et al. (2008).

TABLE 5. Effect of fertilization treatments and irradiation doses on canola seed yield as well as the dry weights of roots, shoots, andtotal dry matter yield of plants $\left(\mathrm{Mg} \mathrm{ha}^{-1}\right)$ irrigated with fresh and treated wastewaters

\begin{tabular}{|c|c|c|c|c|c|c|c|}
\hline \multirow{2}{*}{ 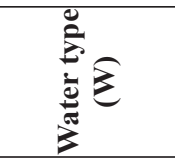 } & \multirow{2}{*}{ 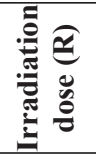 } & \multicolumn{6}{|c|}{ N-fertilization (F) } \\
\hline & & $F_{1}$ & $\mathbf{F}_{2}$ & $\mathbf{F}_{3}$ & $F_{1}$ & $\mathbf{F}_{2}$ & $\mathbf{F}_{3}$ \\
\hline & & \multicolumn{3}{|c|}{ Seed yield, $\mathrm{Mg} \mathrm{ha}^{-1}$} & \multicolumn{3}{|c|}{ Dry weight of whole plants, $\mathrm{Mg} \mathrm{ha}^{-1}$} \\
\hline \multirow{4}{*}{$\begin{array}{l}\text { Fresh } \\
\text { water }\left(\mathbf{W}_{1}\right)\end{array}$} & $\mathrm{R}_{0}$ & $2.186 \mathrm{n}$ & 3.0141 & $3.125 \mathrm{kl}$ & $19.290 \mathrm{~m}$ & $20.220 \mathrm{~lm}$ & 21.990 hijk \\
\hline & $\mathrm{R}_{1}$ & $2.688 \mathrm{~m}$ & $3.375 \mathrm{jk}$ & $4.375 \mathrm{de}$ & $19.890 \mathrm{~lm}$ & $21.450 \mathrm{ijkl}$ & 23.580 efgh \\
\hline & $\mathrm{R}_{2}$ & $2.875 \mathrm{~lm}$ & $3.438 \mathrm{ij}$ & $4.688 \mathrm{c}$ & $20.490 \mathrm{klm}$ & 22.270 hij & $24.310 \mathrm{cdef}$ \\
\hline & $\mathrm{R}_{3}$ & 3.0061 & $3.563 \mathrm{hij}$ & $5.004 \mathrm{~b}$ & $21.030 \mathrm{jkl}$ & 22.820 ghij & 24.950 cde \\
\hline \multirow{5}{*}{$\begin{array}{l}\text { Treated } \\
\text { wastewater } \\
\left(\mathrm{W}_{2}\right)\end{array}$} & $\mathrm{R}_{0}$ & 3.518 hij & $3.313 \mathrm{jk}$ & $3.750 \mathrm{gh}$ & $22.460 \mathrm{klm}$ & 23.500 efgh & $24.420 \mathrm{cdef}$ \\
\hline & $\mathrm{R}_{1}$ & 3.625 ghi & $3.875 \mathrm{fg}$ & $4.508 \mathrm{~cd}$ & 23.400 efgh & $24.240 \mathrm{cdef}$ & $25.810 \mathrm{bcd}$ \\
\hline & $\mathrm{R}_{2}$ & $3.855 \mathrm{fg}$ & $4.125 \mathrm{ef}$ & $5.019 \mathrm{~b}$ & 24.110 defg & 24.930 cde & $26.890 \mathrm{ab}$ \\
\hline & $\mathrm{R}_{3}$ & $3.875 \mathrm{fg}$ & $4.514 \mathrm{~cd}$ & $5.288 \mathrm{a}$ & 25.070 cde & $25.970 \mathrm{bc}$ & $27.800 \mathrm{a}$ \\
\hline & & \multicolumn{3}{|c|}{ Dry weight of roots, $\mathrm{Mg} \mathrm{ha}^{-1}$} & \multicolumn{3}{|c|}{ Dry weight of shoots, $\mathrm{Mg} \mathrm{ha}^{-1}$} \\
\hline \multirow{4}{*}{$\begin{array}{l}\text { Fresh } \\
\text { water }\left(\mathbf{W}_{1}\right)\end{array}$} & $\mathrm{R}_{0}$ & $5.580 \mathrm{j}$ & $6.150 \mathrm{fghi}$ & $6.730 \mathrm{efg}$ & 13.2801 & $13.580 \mathrm{kl}$ & 14.760 hij \\
\hline & $\mathrm{R}_{1}$ & $5.800 \mathrm{ij}$ & $6.210 \mathrm{fghi}$ & $6.900 \mathrm{def}$ & $13.630 \mathrm{jkl}$ & 14.690 hijk & $15.980 \mathrm{defg}$ \\
\hline & $\mathrm{R}_{2}$ & $5.860 \mathrm{hij}$ & 6.560 efghi & 7.190 cde & $14.150 \mathrm{ijkl}$ & 15.150 ghi & $16.360 \mathrm{cdef}$ \\
\hline & $\mathrm{R}_{3}$ & 6.020 ghi & $6.710 \mathrm{efg}$ & $7.310 \mathrm{cde}$ & 14.490 hijk & $15.530 \mathrm{efgh}$ & $16.840 \mathrm{~cd}$ \\
\hline \multirow{4}{*}{$\begin{array}{l}\text { Treated } \\
\text { wastewater } \\
\left(\mathbf{W}_{2}\right)\end{array}$} & $\mathrm{R}_{0}$ & $6.640 \mathrm{efgh}$ & $6.690 \mathrm{efg}$ & $7.110 \mathrm{cde}$ & 15.260 fghi & $16.270 \mathrm{cdef}$ & $16.700 \mathrm{cde}$ \\
\hline & $\mathrm{R}_{1}$ & $6.720 \mathrm{efg}$ & $7.056 \mathrm{cde}$ & $7.612 \mathrm{bcd}$ & $16.090 \mathrm{defg}$ & $16.560 \mathrm{cde}$ & $17.464 \mathrm{bc}$ \\
\hline & $\mathrm{R}_{2}$ & 7.160 cde & $7.280 \mathrm{cde}$ & $7.879 \mathrm{abc}$ & $16.330 \mathrm{cdef}$ & 16.650 cde & $18.197 \mathrm{ab}$ \\
\hline & $\mathrm{R}_{3}$ & $7.756 \mathrm{bc}$ & $8.112 \mathrm{ab}$ & $8.416 \mathrm{a}$ & 16.690 cde & $17.127 \mathrm{bcd}$ & $18.627 \mathrm{a}$ \\
\hline $\begin{array}{l}\text { on- irradia } \\
\text { rganic ferti }\end{array}$ & $\begin{array}{l}\mathrm{R}_{1} \text { : } \\
\text { on }\end{array}$ & $\begin{array}{l}100 \mathrm{~Gy} \text { irra } \\
\mathrm{F}_{2}: \text { minera }\end{array}$ & tion & $\begin{array}{l}\mathrm{R}_{2}: 200 \mathrm{~Gy} \\
\mathrm{~F}_{3}: \text { miner }\end{array}$ & $\begin{array}{l}\text { diation } \\
\text { organic fert }\end{array}$ & \multicolumn{2}{|c|}{$\mathrm{R}_{3}: 300 \mathrm{~Gy}$ irradiation. } \\
\hline
\end{tabular}

Env. Biodiv. Soil Security Vol. 4 (2020) 

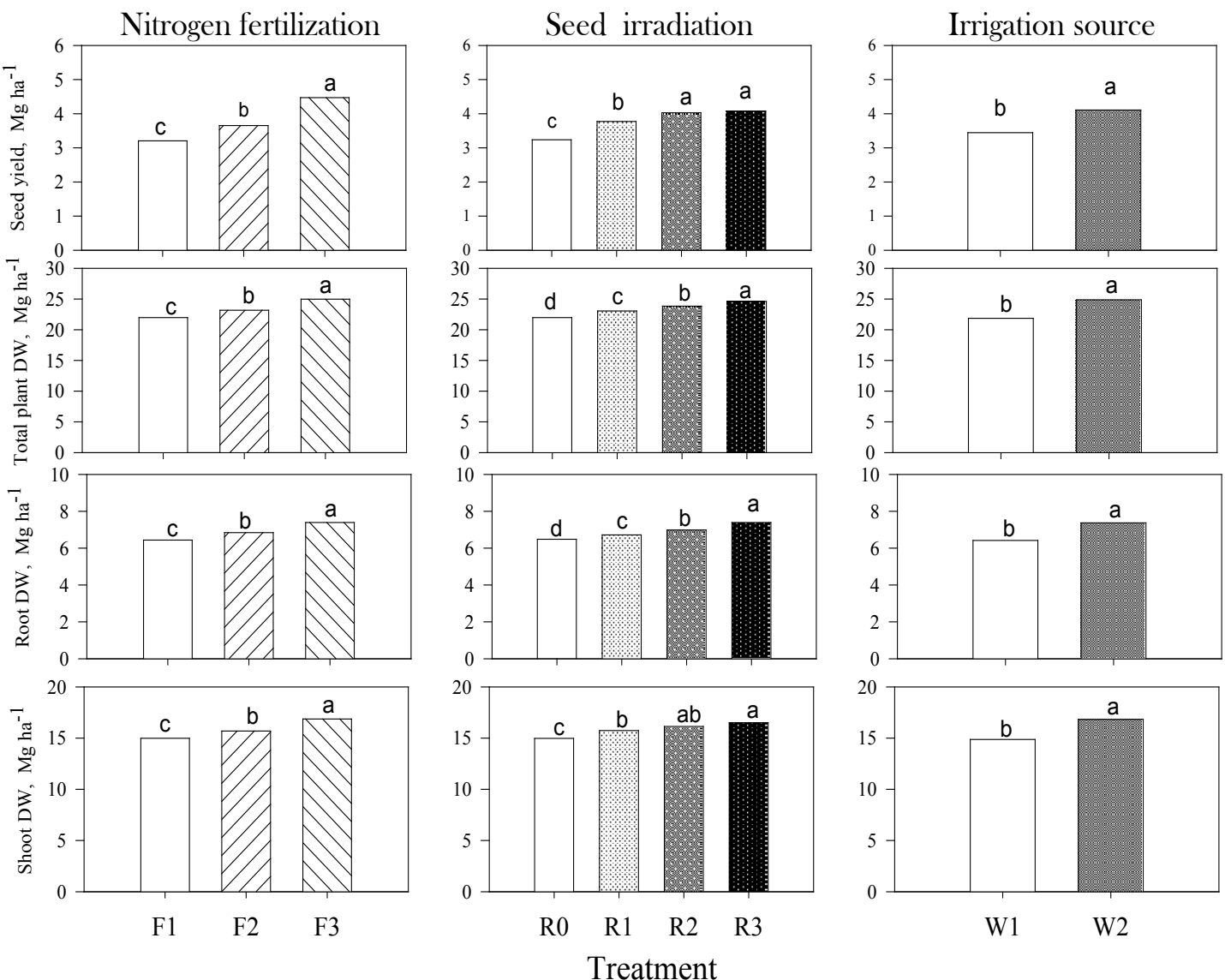

Fig . 1. Grand means of the effects of fertilization treatments and irradiation doses on canola seed yield as well as the dry weights of roots, shoots, and total dry matter yield of plants $\left(\mathrm{Mg} \mathrm{ha}^{-1}\right)$ irrigated with fresh and treated wastewaters. Similar letters indicate no significant variations among treatments

The combined fertilization treatment (F3) recorded the highest increases in $\mathrm{N}$-uptake within different plant parts versus application of either ammonium sulfate or compost solely. It seems that ammonium sulphate enriched soils with $\mathrm{N}$ which is needed for plant growth. On the other hand, $\mathrm{N}$ was subjected to excessive $\mathrm{N}$ leaching in sandy soils (Shareef et al. 2019); yet, its combination with compost might effectively reduce $\mathrm{N}$ leaching loss from soils (Xu et al. 2020). Accordingly, $N$ uptake increased and accumulated within different canola plant parts owing to $\mathrm{N}$ fertilization (Svečnjak and Rengel 2006).

Wastewater acted also as a nutritive source; consequently, irrigation with wastewater increased significantly the amounts of $\mathrm{N}$ accumulated within different plant parts. Such a result agree with the findings of Mohammed and Ayadi (2004) who found that nitrogen absorption by maize grains increased significantly due to irrigation with treated wastewater. Thus, irrigation with treated wastewater may benefit agricultural crops with water and basic nutrients, mainly nitrogen (Leal et al., 2009 and Ali, 2016). It seems that nitrogen uptake were higher in shoots than in roots. Furthermore, the highest values of $\mathrm{N}$ uptake were recorded in seeds. As mentioned above, radiated seeds grown on a soil amended with the combined $\mathrm{N}$-fertilizers recorded the highest increases in N-uptake especially when canola plants were irrigated with wastewater. These three factors increased significantly $\mathrm{N}$-uptake by plants by approximately 2.4 folds higher that the reference treatment (irradiated seeds amended with mineral $\mathrm{N}$-fertilizer solely and irrigated with fresh Nile water.

\section{P uptake}

As listed in Table 7 and Fig. 3, the nonirradiated plants that were irrigated with fresh water reflected gradual increase in $\mathrm{P}$ uptake by roots due to application of mineral-N fertilizer combined with organic compost $(50 \%$ 
TABLE 6. Effect of fertilization treatments and irradiation doses on nitrogen uptake $\left(\mathrm{kg} \mathrm{ha}^{-1}\right)$ by root, shoot, seeds, and the whole canola plant irrigated with fresh and treated wastewaters

\begin{tabular}{|c|c|c|c|c|c|c|c|}
\hline \multirow{2}{*}{ 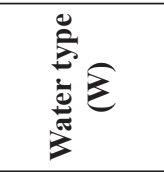 } & \multirow{2}{*}{ 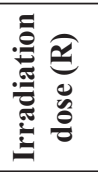 } & \multicolumn{6}{|c|}{ N-Fertilization (F) } \\
\hline & & $\mathbf{F}_{1}$ & $\mathbf{F}_{2}$ & $\mathbf{F}_{3}$ & $\mathrm{~F}_{1}$ & $\mathbf{F}_{2}$ & $\mathbf{F}_{3}$ \\
\hline & & \multicolumn{3}{|c|}{ Nitrogen uptake by roots, $\mathrm{kg} \mathrm{ha}^{-1}$} & \multicolumn{3}{|c|}{ Nitrogen uptake by shoots, $\mathrm{kg} \mathrm{ha}^{-1}$} \\
\hline \multirow{4}{*}{$\begin{array}{l}\text { Fresh } \\
\text { water }\left(\mathrm{W}_{1}\right)\end{array}$} & $\mathrm{R}_{0}$ & 11.431 & $14.53 \mathrm{kl}$ & $17.33 \mathrm{jk}$ & 25.501 & $22.50 \mathrm{~m}$ & $24.50 \mathrm{~lm}$ \\
\hline & $\mathrm{R}_{1}$ & $18.43 \mathrm{jk}$ & $21.50 \mathrm{ij}$ & $25.50 \mathrm{hi}$ & $28.70 \mathrm{jk}$ & $36.33 \mathrm{gh}$ & $29.37 \mathrm{j}$ \\
\hline & $\mathrm{R}_{2}$ & $31.50 \mathrm{efg}$ & $33.37 \mathrm{defg}$ & $38.43 \mathrm{bcd}$ & $29.60 \mathrm{j}$ & $39.60 \mathrm{e}$ & $35.83 \mathrm{~h}$ \\
\hline & $\mathrm{R}_{3 \ldots}$ & $28.40 \mathrm{gh}$ & 36.33 cde & $42.50 \mathrm{~b}$ & $36.53 \mathrm{fgh}$ & $39.33 \mathrm{e}$ & $45.43 \mathrm{~d}$ \\
\hline \multirow{4}{*}{$\begin{array}{l}\text { Treated } \\
\text { wastewater } \\
\left(\mathrm{W}_{2}\right)\end{array}$} & $\mathrm{R}_{0}$ & $21.57 \mathrm{ij}$ & $25.43 \mathrm{hi}$ & $27.40 \mathrm{gh}$ & $26.70 \mathrm{kl}$ & $28.93 \mathrm{jk}$ & $26.50 \mathrm{kl}$ \\
\hline & $\mathrm{R}_{1}^{0}$ & $28.37 \mathrm{gh}$ & $34.47 \mathrm{def}$ & $39.03 \mathrm{bcd}$ & $32.70 \mathrm{i}$ & $38.70 \mathrm{efg}$ & $36.23 \mathrm{gh}$ \\
\hline & $\mathrm{R}_{2}$ & $29.63 \mathrm{fgh}$ & 37.13 bcde & $41.97 \mathrm{bc}$ & 39.00 ef & $39.37 \mathrm{e}^{8}$ & $49.57 \mathrm{~b}$ \\
\hline & $\mathrm{R}_{3}$ & 35.33 def & $41.77 \mathrm{bc}$ & $54.37 \mathrm{a}$ & $46.90 \mathrm{~cd}$ & $48.53 \mathrm{bc}$ & $56.60 \mathrm{a}$ \\
\hline & & \multicolumn{3}{|c|}{ Nitrogen uptake by seeds, $\mathrm{kg} \mathrm{ha}^{-1}$} & \multicolumn{3}{|c|}{ Total nitrogen uptake, $\mathrm{kg} \mathrm{ha}^{-1}$} \\
\hline \multirow{4}{*}{$\begin{array}{l}\text { Fresh } \\
\text { water }\left(\mathrm{W}_{1}\right)\end{array}$} & $\mathrm{R}_{0}$ & $28.50 \mathrm{i}$ & $29.27 \mathrm{i}$ & $31.27 \mathrm{i}$ & 69.371 & 70.131 & $79.37 \mathrm{k}$ \\
\hline & $\mathrm{R}_{1}$ & $35.17 \mathrm{~h}$ & $38.70 \mathrm{fg}$ & $48.10 \mathrm{~d}$ & $82.30 \mathrm{k}$ & $106.53 \mathrm{~h}$ & $105.87 \mathrm{~h}$ \\
\hline & $\mathrm{R}_{2}$ & $39.43 \mathrm{efg}$ & $42.53 \mathrm{e}$ & $48.53 \mathrm{~cd}$ & $90.53 \mathrm{j}$ & $115.50 \mathrm{fg}$ & $122.20 \mathrm{ef}$ \\
\hline & $\mathrm{R}_{3}$ & $46.23 \mathrm{~d}$ & $51.43 \mathrm{bc}$ & $52.33 \mathrm{~b}$ & $110.27 \mathrm{gh}$ & $129.20 \mathrm{de}$ & $140.57 \mathrm{c}$ \\
\hline \multirow{4}{*}{$\begin{array}{l}\text { Treated } \\
\text { wastewater } \\
\left(\mathrm{W}_{2}\right)\end{array}$} & $\mathrm{R}_{0}$ & $29.43 \mathrm{i}$ & $30.13 \mathrm{i}$ & $38.70 \mathrm{fg}$ & $77.70 \mathrm{k}$ & $84.50 \mathrm{jk}$ & $84.77 \mathrm{jk}$ \\
\hline & $\mathrm{R}_{1}$ & $36.90 \mathrm{gh}$ & 41.77 ef & $49.33 \mathrm{bcd}$ & $97.97 \mathrm{i}$ & $114.93 \mathrm{fg}$ & $124.60 \mathrm{de}$ \\
\hline & $\mathrm{R}_{2}$ & $39.63 \mathrm{efg}$ & $46.93 \mathrm{~d}$ & $57.97 \mathrm{a}$ & $108.27 \mathrm{gh}$ & $123.47 \mathrm{de}$ & $149.50 \mathrm{~b}$ \\
\hline & $\mathrm{R}_{3}$ & $49.23 \mathrm{bcd}$ & $56.50 \mathrm{a}$ & $58.87 \mathrm{a}$ & $131.47 \mathrm{~d}$ & $146.80 \mathrm{bc}$ & $169.83 \mathrm{a}$ \\
\hline
\end{tabular}

$\mathrm{R}_{0}$ : non- irradiation $\quad \mathrm{R}_{1}: 100 \mathrm{~Gy}$ irradiation $\quad \mathrm{R}_{2}: 200 \mathrm{~Gy}$ irradiation $\quad \mathrm{R}_{3}: 300 \mathrm{~Gy}$ irradiation $\mathrm{F}_{1}$ : organic fertilization $\quad \mathrm{F}_{2}$ : mineral fertilization $\quad \mathrm{F}_{3}$ : mineral + organic fertilization
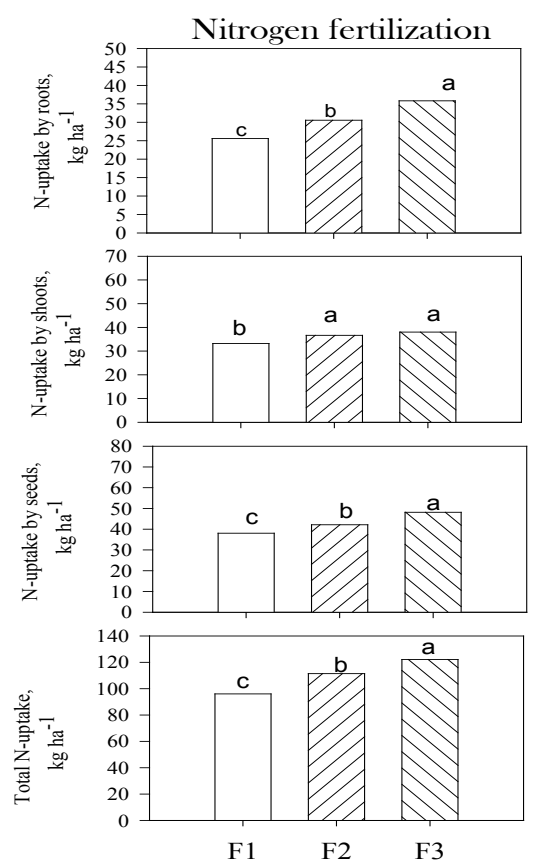
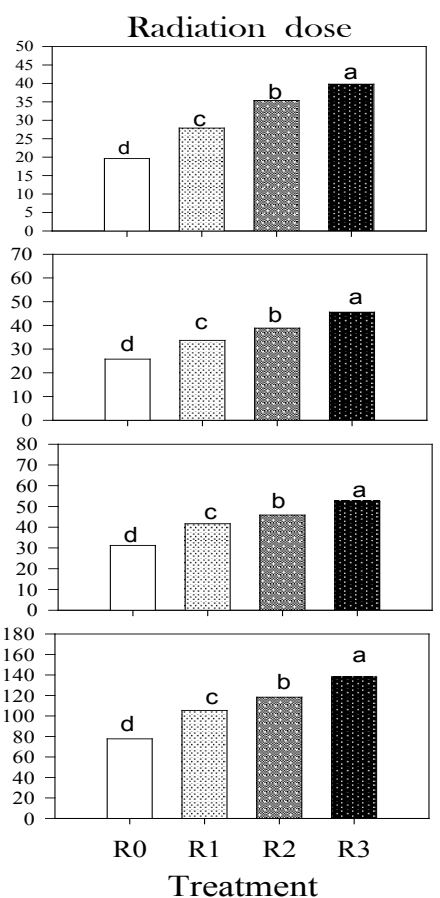
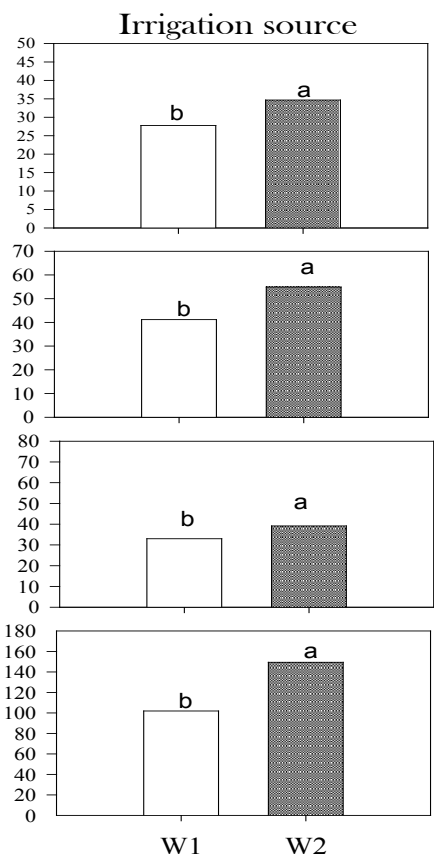

Fig. 2. Grand means of the effects of fertilization treatments and irradiation doses on nitrogen uptake (kg ha- 1) by root, shoot, seeds, and the whole canola plant irrigated with fresh and treated wastewater. Similar letters indicate no significant variations among treatments.

Env. Biodiv. Soil Security Vol. 4 (2020) 
mineral-N $+50 \% \quad$ organic-N, F3). Similarly, the uptake of phosphorus in irradiated plants was more along with combined fertilizer but, to somewhat, higher than the non-irradiated ones. The highest values of $\mathrm{P}$ uptake by roots were achieved with the application of F3 in combination with the highest used irradiation dose (300 Gy). Such increases may be related to the concurrent increases that occurred in plant roots and; hence, the uptake of soil nutrients by plants increased. Moreover, gamma radiation might regulate and stimulate further P-carriers in plant roots; however, this point needs further evidences.

In case of plants irrigated with treated wastewater, $\mathrm{P}$ uptake by roots was enhanced as compared to those irrigated with fresh water. Nevertheless, the obtained values followed the same trend as the ones affected by nitrogen fertilizer treatments (F3) and high gamma irradiation dose (R3). Also, increasing gamma dose in conjunction with F3 induced the highest values of $\mathrm{P}$ uptake by shoots and seeds. In this respect, both shoots and seeds had more $\mathrm{P}$ than roots whose values seemed to be nearly closed to each other. In this regard, roots of canola are known to act as a storage reservoir for $\mathrm{N}$, but not for P (Rossato et al., 2002). Previous work constructed by Rose et al. (2007) reflected that canola cultivars accumulated more $\mathrm{P}$ and continued uptake until a later stage (peaked at flowering growth stage).

\section{Potassium uptake}

Roots, shoots and seeds of canola plants accumulated more potassium in their tissues when plants were exposed to 300 Gy gamma ray dose comparing to the other levels of irradiation

TABLE 7. Effect of fertilization treatments and irradiation doses on phosphorus uptake (kg ha-1) by root, shoot, seeds, and the whole canola plant irrigated with fresh and treated wastewater.

\begin{tabular}{|c|c|c|c|c|c|c|c|}
\hline \multirow{2}{*}{$\begin{array}{l}\text { Water type } \\
\text { (W) }\end{array}$} & \multirow{2}{*}{$\begin{array}{c}\text { Irradiation } \\
\text { dose }(\mathbf{R})\end{array}$} & \multicolumn{6}{|c|}{ N-Fertilization (F) } \\
\hline & & $F_{1}$ & $\mathbf{F}_{2}$ & $\mathbf{F}_{3}$ & $\mathrm{~F}_{1}$ & $\mathbf{F}_{2}$ & $\mathbf{F}_{3}$ \\
\hline & & \multicolumn{3}{|c|}{ Phosphors uptake by root } & \multicolumn{3}{|c|}{ Phosphors uptake by shoots } \\
\hline \multirow{4}{*}{$\begin{array}{l}\text { Fresh water } \\
\left(\mathrm{W}_{1}\right)\end{array}$} & $\mathrm{R}_{0}$ & $6.30 \mathrm{j}$ & $11.53 \mathrm{hi}$ & $10.77 \mathrm{hi}$ & $13.00 \mathrm{n}$ & $19.20 \mathrm{kl}$ & $22.53 \mathrm{j}$ \\
\hline & $\mathrm{R}_{1}$ & $10.53 \mathrm{i}$ & $12.37 \mathrm{hi}$ & $25.30 \mathrm{e}$ & $21.30 \mathrm{jk}$ & $29.30 \mathrm{~h}$ & $35.27 \mathrm{f}$ \\
\hline & $\mathrm{R}_{2}$ & $12.50 \mathrm{~h}$ & $19.10 \mathrm{~g}$ & $30.67 \mathrm{~d}$ & $27.87 \mathrm{hi}$ & 37.10 ef & $39.37 \mathrm{e}$ \\
\hline & $\mathrm{R}_{3}$ & $19.37 \mathrm{~g}$ & $22.60 \mathrm{f}$ & $38.23 \mathrm{~b}$ & $32.47 \mathrm{~g}$ & $45.07 \mathrm{bc}$ & $42.83 \mathrm{~cd}$ \\
\hline \multirow{5}{*}{$\begin{array}{l}\text { Treated } \\
\text { wastewater } \\
\left(\mathrm{W}_{2}\right)\end{array}$} & $\mathrm{R}_{0}$ & $11.20 \mathrm{hi}$ & $12.13 \mathrm{hi}$ & $18.30 \mathrm{~g}$ & $15.30 \mathrm{~m}$ & 18.371 & $26.70 \mathrm{i}$ \\
\hline & $\mathrm{R}_{1}$ & $12.33 \mathrm{hi}$ & $29.27 \mathrm{~d}$ & $39.20 \mathrm{~b}$ & $28.30 \mathrm{hi}$ & $39.23 \mathrm{e}$ & $42.40 \mathrm{~d}$ \\
\hline & $\mathrm{R}_{2}$ & $18.23 \mathrm{~g}$ & $33.03 \mathrm{c}$ & $41.30 \mathrm{a}$ & $29.37 \mathrm{~h}$ & $39.40 \mathrm{e}$ & $46.40 \mathrm{~b}$ \\
\hline & $\mathrm{R}_{3}$ & $24.30 \mathrm{e}$ & $41.93 \mathrm{a}$ & $41.30 \mathrm{a}$ & $32.50 \mathrm{~g}$ & $47.03 \mathrm{~b}$ & $52.50 \mathrm{a}$ \\
\hline & & \multicolumn{3}{|c|}{ Phosphors uptake by seeds } & \multicolumn{3}{|c|}{ Total P-uptake by plants } \\
\hline \multirow{4}{*}{$\begin{array}{l}\text { Fresh water } \\
\left(\mathrm{W}_{1}\right)\end{array}$} & $\mathrm{R}_{0}$ & $16.30 \mathrm{j}$ & $18.50 \mathrm{j}$ & $21.43 \mathrm{i}$ & 35.601 & $46.20 \mathrm{k}$ & $54.73 \mathrm{j}$ \\
\hline & $\mathrm{R}_{1}$ & $22.30 \mathrm{i}$ & $28.43 \mathrm{~h}$ & $32.10 \mathrm{~g}$ & $54.13 \mathrm{j}$ & $70.10 \mathrm{hi}$ & $82.67 \mathrm{~g}$ \\
\hline & $\mathrm{R}_{2}$ & $27.67 \mathrm{~h}$ & $29.27 \mathrm{~h}$ & $36.47 \mathrm{cde}$ & $66.53 \mathrm{i}$ & $85.47 \mathrm{~g}$ & $106.50 \mathrm{de}$ \\
\hline & $\mathrm{R}_{3}$ & 34.80 ef & $38.43 \mathrm{c}$ & $42.33 \mathrm{~b}$ & $86.63 \mathrm{~g}$ & $106.10 \mathrm{de}$ & $123.40 \mathrm{c}$ \\
\hline \multirow{4}{*}{$\begin{array}{l}\text { Treated } \\
\text { wastewater } \\
\left(\mathrm{W}_{2}\right)\end{array}$} & $\mathrm{R}_{0}$ & $26.80 \mathrm{~h}$ & $28.40 \mathrm{~h}$ & $28.77 \mathrm{~h}$ & $53.30 \mathrm{j}$ & $58.90 \mathrm{j}$ & $75.03 \mathrm{~h}$ \\
\hline & $\mathrm{R}_{1}$ & $32.47 \mathrm{fg}$ & $34.67 \mathrm{ef}$ & $38.67 \mathrm{c}$ & $73.10 \mathrm{~h}$ & $103.17 \mathrm{e}$ & $120.27 \mathrm{c}$ \\
\hline & $\mathrm{R}_{2}$ & $35.73 \mathrm{de}$ & $38.43 \mathrm{c}$ & $44.67 \mathrm{~b}$ & $83.33 \mathrm{~g}$ & $110.87 \mathrm{~d}$ & $132.37 \mathrm{~b}$ \\
\hline & $\mathrm{R}_{3}$ & $37.40 \mathrm{~cd}$ & $44.33 \mathrm{~b}$ & $52.60 \mathrm{a}$ & $93.63 \mathrm{f}$ & $133.30 \mathrm{~b}$ & $152.37 \mathrm{a}$ \\
\hline
\end{tabular}



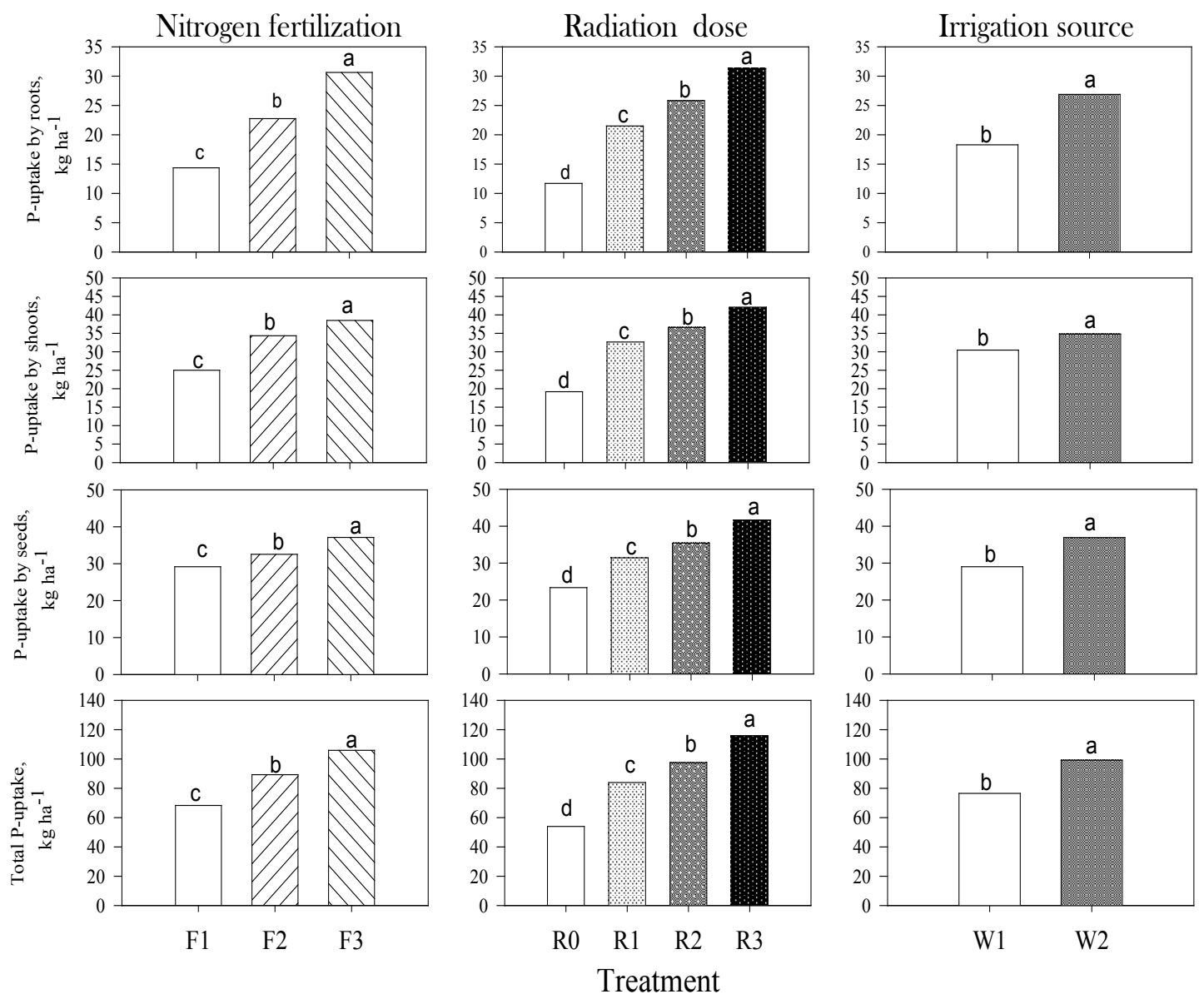

Fig. 3. Grand means of the effects of fertilization treatments and irradiation doses on phosphorus uptake (kg ha1) by root, shoot, seeds, and the whole canola plant irrigated with fresh and treated wastewater. Similar letters indicate no significant variations among treatments.

or the non-irradiated control (Table 8 and Fig. 4). Also, these values of $\mathrm{K}$ uptake were enhanced by addition of the combined fertilization treatment $(50 \%$ mineral-N $+50 \%$ organic- $\mathrm{N})$ followed by those of $100 \%$ mineral-N then organic-N. This might occur because of the steady increases that took place in K-availability in soil during compost decomposition (Farid et al. 2018).

Plants irrigated with treated wastewater raised slightly; however, significantly $\mathrm{K}$ uptake in all plant organs as compared to those irrigated with fresh water. This result agrees with Galavi et al. (2010) who found that potassium uptake increased due to irrigation with treated wastewater compared to those irrigated with the fresh water. It seems that accumulation of $\mathrm{K}$ in seeds were low comparable to other plant parts and this did not contradict with the given fact that $\mathrm{K}$ is has high phloem mobility (Epstein, 1972). Probably, little K was translocated from canola leaves and petioles before senescence, causing substantial losses and negligible redistribution of $\mathrm{K}$ from clique walls to the seed (Rose et al. 2007). These abovementioned results indicate that the highest level (300 Gy) of gamma irradiation resulted in the highest $\mathrm{K}$ uptake, especially under fertilization with combined organic plus mineral-N and irrigation with treated wastewater.

\section{Oil production}

Canola oil yield increased significantly in the irradiated plants, especially with increasing the irradiation dose (Table 9 and Fig. 5). On line, Yassein and Aly (2014) found that 300 Gy was the most effective dose among the five gamma rays levels which produced the highest oil content in three Brassica genotypes (46.7\% higher than the control). Also, Vaizoğullar et al. (2016) found that the crude oil yield of sunflower was not significantly increased due to irradiation with 100 and 200 Gy while the highest crude oil yield was achieved due to irrediation with $400 \mathrm{~Gy}$ dose. 
This positive effect of gamma irradiation may be attributed to cytological, biochemical, physiological, morphological and genetically changes in cells and tissues (Kiong et al. 2008). The biological effect of gamma-rays is based on the interaction with atoms or molecules in the cell, particularly water, to produce free radicals (Kovacs and Keresztes, 2002). It was found that such mutagenic treatment produced the highest oil content (Javed et al. 2003; Hassan and AbdEll-Haleem, 2014). Likewise, the source of $\mathrm{N}$-fertilizer affected significantly canola oil yield. In this concern, the combined treatment $(50 \%$ mineral- $\mathrm{N}+50 \%$ organic-N $)$ exhibited the highest increases, followed by the $100 \%$ organic- $\mathrm{N}$ (compost), then the mineral treatment
$(100 \%$ mineral-N). Plants irrigated with treated wastewater produced, to some extent, more oil than those recorded with plants irrigated with fresh water. Similar findings were earlier reported by Sarwar et al. (2010) and Kotb and Moursy (2018), who also found that oil yield was significantly higher in canola plants irrigated with treated wastewater than the corresponding ones irrigated with Freshwater.

Multivariate analyses among NPK uptake by canola and plant growth parameters and seed yield

Table 10 reveals that the dry weights of canola roots, shoots and seeds correlated significantly with the NPK uptake by plants.

TABLE 8. Effect of fertilization treatments and irradiation doses on potassium uptake ( $\left.\mathrm{kg} \mathrm{ha}^{-1}\right)$ by root, shoot, seeds, and the whole canola plant irrigated with fresh and treated wastewater.

\begin{tabular}{|c|c|c|c|c|c|c|c|}
\hline \multirow{2}{*}{$\begin{array}{c}\text { Water type } \\
\text { (W) }\end{array}$} & \multirow{2}{*}{$\begin{array}{c}\text { Irradiation } \\
\text { doses }(\mathbf{R})\end{array}$} & \multicolumn{6}{|c|}{ N-Fertilization (F) } \\
\hline & & $\mathbf{F}_{1}$ & $\mathbf{F}_{2}$ & $\mathbf{F}_{3}$ & $\mathbf{F}_{1}$ & $\mathbf{F}_{2}$ & $\mathbf{F}_{3}$ \\
\hline & & \multicolumn{3}{|c|}{ potassium uptake by root } & \multicolumn{3}{|c|}{ Potassium uptake by shoots } \\
\hline \multirow{4}{*}{$\begin{array}{l}\text { Fresh water } \\
\left(\mathrm{W}_{1}\right)\end{array}$} & $\mathrm{R}_{0}$ & 23.271 & $28.50 \mathrm{jk}$ & $30.73 \mathrm{ij}$ & $35.93 \mathrm{jk}$ & $32.60 \mathrm{k}$ & $33.03 \mathrm{k}$ \\
\hline & $\mathrm{R}_{1}$ & $26.30 \mathrm{k}$ & $35.10 \mathrm{~h}$ & $41.33 \mathrm{efg}$ & $38.47 \mathrm{ij}$ & $41.63 \mathrm{i}$ & $52.37 \mathrm{efg}$ \\
\hline & $\mathrm{R}_{2}$ & $32.50 \mathrm{hi}$ & $39.63 \mathrm{fg}$ & $49.43 \mathrm{~cd}$ & $39.47 \mathrm{ij}$ & $48.53 \mathrm{~h}$ & $61.93 \mathrm{c}$ \\
\hline & $\mathrm{R}_{3}$ & $39.47 \mathrm{fg}$ & 42.27 ef & $51.37 \mathrm{bc}$ & $49.10 \mathrm{gh}$ & $53.03 \mathrm{ef}$ & $66.30 \mathrm{ab}$ \\
\hline \multirow{5}{*}{$\begin{array}{l}\text { Treated } \\
\text { wastewater } \\
\left(\mathrm{W}_{2}\right)\end{array}$} & $\mathrm{R}_{0}$ & $28.33 \mathrm{jk}$ & $29.17 \mathrm{jk}$ & $32.70 \mathrm{hi}$ & $39.20 \mathrm{ij}$ & $37.43 \mathrm{j}$ & $36.80 \mathrm{j}$ \\
\hline & $\mathrm{R}_{1}$ & $38.40 \mathrm{~g}$ & $38.37 \mathrm{~g}$ & $43.37 \mathrm{e}$ & $39.47 \mathrm{ij}$ & $48.63 \mathrm{~h}$ & $57.40 \mathrm{~d}$ \\
\hline & $\mathrm{R}_{2}$ & $39.50 \mathrm{fg}$ & $48.20 \mathrm{~d}$ & $51.43 \mathrm{bc}$ & $41.57 \mathrm{i}$ & $52.03 \mathrm{fgh}$ & $65.67 \mathrm{~b}$ \\
\hline & $\mathrm{R}_{3}$ & $49.47 \mathrm{~cd}$ & $52.50 \mathrm{~b}$ & $61.77 \mathrm{a}$ & $55.57 \mathrm{de}$ & $58.30 \mathrm{~d}$ & $69.30 \mathrm{a}$ \\
\hline & & \multicolumn{3}{|c|}{ Potassium uptake by seed } & \multicolumn{3}{|c|}{ Total K uptake by plants } \\
\hline \multirow{4}{*}{$\begin{array}{l}\left(\mathrm{W}_{1}\right) \text { Fresh } \\
\text { water }\end{array}$} & $\mathrm{R}_{0}$ & $5.30 \mathrm{n}$ & 9.271 & 9.431 & $64.50 \mathrm{~m}$ & $60.67 \mathrm{~m}$ & $73.201 \mathrm{~m}$ \\
\hline & $\mathrm{R}_{1}$ & $6.90 \mathrm{mn}$ & $14.27 \mathrm{j}$ & $18.13 \mathrm{i}$ & $84.23 \mathrm{jkl}$ & $91.90 \mathrm{ijk}$ & $112.43 \mathrm{fg}$ \\
\hline & $\mathrm{R}_{2}$ & $8.47 \mathrm{~lm}$ & $18.37 \mathrm{i}$ & $19.40 \mathrm{i}$ & $80.43 \mathrm{kl}$ & $106.53 \mathrm{fgh}$ & $130.77 \mathrm{e}$ \\
\hline & $\mathrm{R}_{3}$ & $11.87 \mathrm{k}$ & $19.67 \mathrm{i}$ & $27.33 \mathrm{f}$ & 96.87hij & $114.97 \mathrm{f}$ & $145.00 \mathrm{bcd}$ \\
\hline \multirow{4}{*}{$\begin{array}{l}\left(\mathrm{W}_{2}\right) \text { treated } \\
\text { wastewater }\end{array}$} & $\mathrm{R}_{0}$ & $21.83 \mathrm{~h}$ & $28.17 \mathrm{ef}$ & $29.30 \mathrm{e}$ & $89.37 \mathrm{ijk}$ & 94.77hij & 98.80ghi \\
\hline & $\mathrm{R}_{1}$ & $25.10 \mathrm{~g}$ & $29.23 \mathrm{e}$ & $38.07 \mathrm{~b}$ & 102.97fghi & $106.23 \mathrm{fgh}$ & $136.80 \mathrm{cde}$ \\
\hline & $\mathrm{R}_{2}$ & $29.77 \mathrm{e}$ & $33.27 \mathrm{~d}$ & $39.43 \mathrm{~b}$ & $107.50 \mathrm{fgh}$ & $133.50 \mathrm{de}$ & $156.53 b$ \\
\hline & $\mathrm{R}_{3}$ & $35.23 \mathrm{c}$ & $39.33 \mathrm{~b}$ & $42.37 \mathrm{a}$ & $140.27 \mathrm{cde}$ & $150.13 b c$ & $173.43 \mathrm{a}$ \\
\hline
\end{tabular}



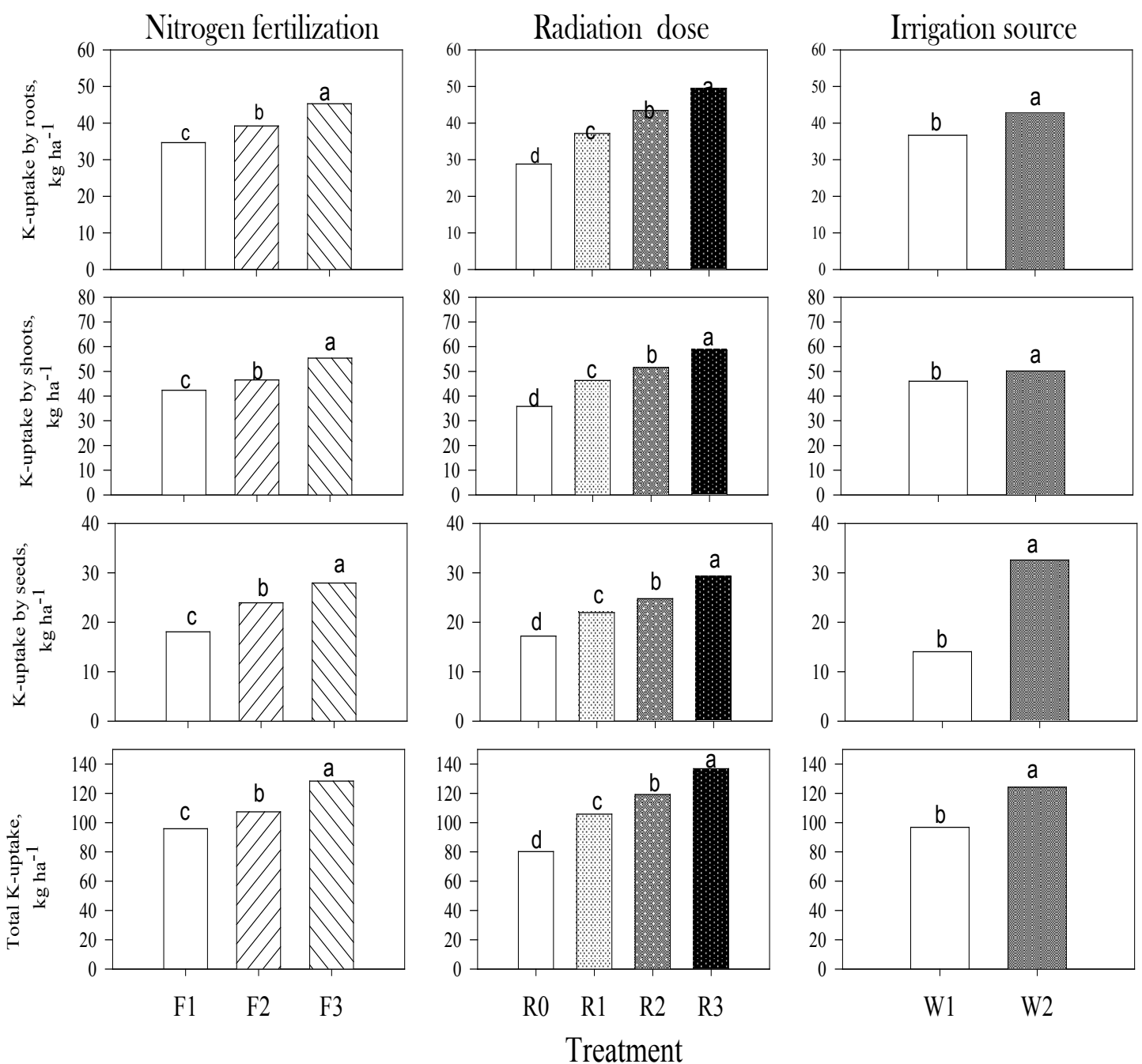

Fig. 4. Grand means of the effect of fertilization treatments and irradiation doses on potassium uptake $\left(\mathrm{kg} \mathrm{ha}^{-1}\right)$ by root, shoot, seeds, and the whole canola plant irrigated with fresh and treated wastewater. Similar letters indicate no significant variations among treatments

TABLE 9. Effect of fertilization treatments and irradiation doses on oil productivity of canola plants irrigated with the Nile fresh and treated wastewater.

\begin{tabular}{|c|c|c|c|c|}
\hline \multirow{2}{*}{ Water type } & \multirow{2}{*}{$\begin{array}{l}\text { Irradiation } \\
\text { dose }\end{array}$} & \multicolumn{3}{|c|}{ Oil production $\left(\mathrm{kg} \mathrm{ha}^{-1}\right)$} \\
\hline & & $\mathrm{F}_{1}$ & $\mathbf{F}_{2}$ & $\mathbf{F}_{3}$ \\
\hline \multirow{4}{*}{$\begin{array}{l}\left(\mathrm{W}_{1}\right) \text { Fresh } \\
\text { water }\end{array}$} & $\mathrm{R}_{0}$ & $812.70 \mathrm{n}$ & $922.50 \mathrm{~lm}$ & $985.31 \mathrm{kl}$ \\
\hline & $\mathrm{R}_{1}$ & $878.60 \mathrm{mn}$ & $1066.50 \mathrm{jk}$ & 1467.81 efg \\
\hline & $\mathrm{R}_{2}$ & $924.00 \mathrm{~lm}$ & $1109.63 \mathrm{ij}$ & $1430.63 \mathrm{fgh}$ \\
\hline & $\mathrm{R}_{3}$ & $956.57 \mathrm{~lm}$ & $1156.03 \mathrm{ij}$ & $1816.5 \mathrm{c}$ \\
\hline \multirow{4}{*}{$\begin{array}{l}\left(\mathrm{W}_{2}\right) \text { treated } \\
\text { wastewater }\end{array}$} & $\mathrm{R}_{0}$ & $1172.15 \mathrm{i}$ & $1155.40 \mathrm{ij}$ & $1347.00 \mathrm{~h}$ \\
\hline & $\mathrm{R}_{1}$ & $1368.44 \mathrm{~h}$ & $1418.25 \mathrm{gh}$ & $1771.20 \mathrm{c}$ \\
\hline & $\mathrm{R}_{2}$ & $1492.26 \mathrm{efg}$ & $1555.13 \mathrm{de}$ & $2059.50 \mathrm{~b}$ \\
\hline & $\mathrm{R}_{3}$ & $1526.75 \mathrm{def}$ & $1601.55 \mathrm{~d}$ & $2236.61 \mathrm{a}$ \\
\hline $\begin{array}{l}k_{0}: \text { non- irradiatic } \\
{ }_{1}: \text { organic fertili }\end{array}$ & tion & $\begin{array}{l}\text { Gy irradiation } \\
\text { eral fertilization }\end{array}$ & $\begin{array}{l}\mathrm{R}_{2}: 200 \mathrm{~Gy} \mathrm{irr} \\
\mathrm{F}_{3}: \text { mineral }+\end{array}$ & fertilization \\
\hline
\end{tabular}

Env. Biodiv. Soil Security Vol. 4 (2020) 

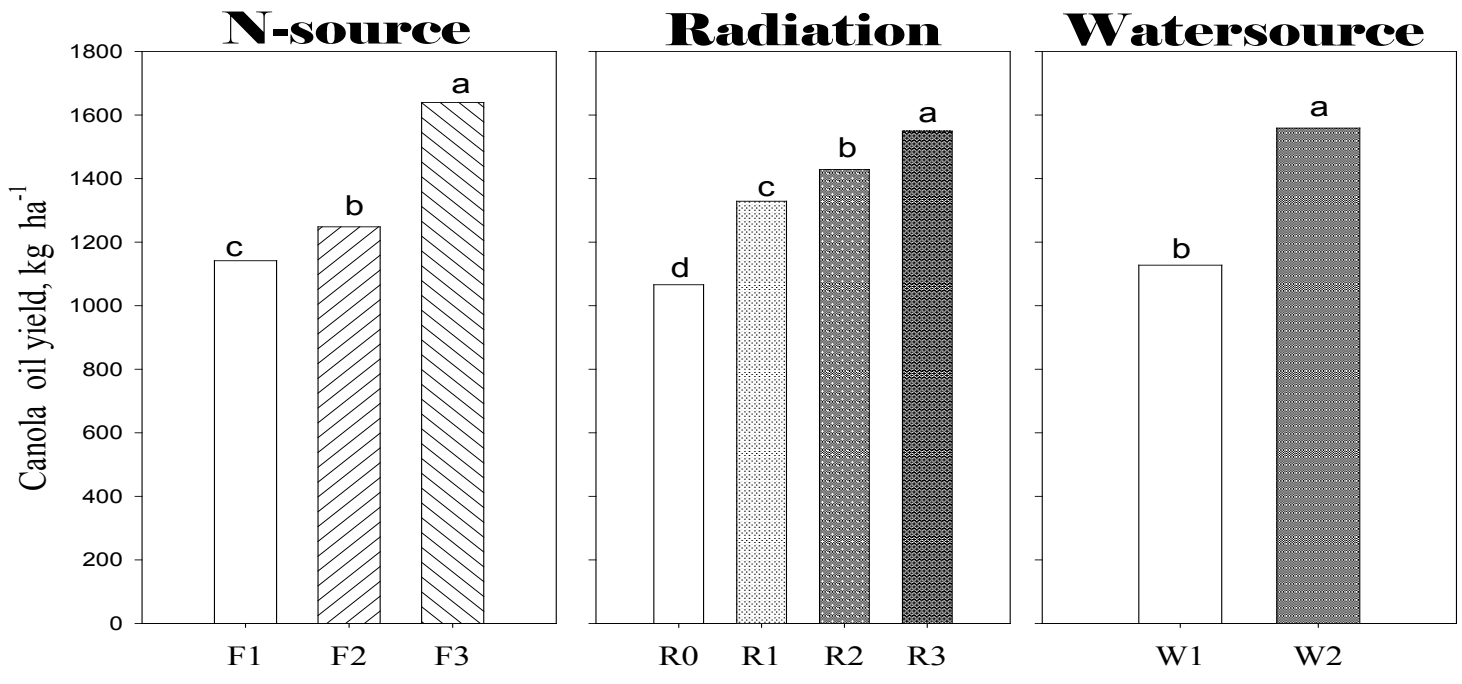

Treatment

Fig. 5. Grand Means of fertilization treatments and irradiation doses on oil productivity of canola plants irrigated with the Nile fresh and treated wastewater.

Moreover, there were significant correlations among concentrations of NPK within different plant parts. It seems that oil productivity of canola plants was also highly correlated with the concurrent increases that took place in the uptake of nutrients (NPK). Such results indicate the significance of soil nutrition in increasing plant productivity.

\section{Conclusion}

Management of nitrogen inputs is required to increase canola growth, seed yield, oil productivity and NPK accumulation in different plant organs. In this concern, the combined treatment of $50 \%$ mineral-N plus $50 \%$ organic-N exerted the highest values of the yield measured parameters comparing to either full dose of mineral-N or the sole organic application. Similarly, a positive effect of gamma radiation was detected. Increasing $Y$ ray dose from 100 to 300 Gy induced an enhancement of dry matter yield (shoot and root), seed yield, and nutrients uptake and oil productivity. Also, all tested parameters were positively increased over the non-irradiated plants. It seems that seed irradiation with $\mathrm{Y}$-rays induced stress on false recognition. Accordingly, it stimulated more nutrient import carriers, and on the other hand accelerated their transportations from roots and shoots towards the reproductive growth parts (seeds) of canola plants. This may explain why, the seed yield increased by approximately two folds higher than the reference treatment; yet, the corresponding increases in either root or shoot DW did not exceed 1.5 folds. Amending soils with the recommended doses of soil nutrients might not be the optimum choice to increase the productivity of such hunger plants grown in such a low-fertile sandy soil. More nutrients should be added to fulfill their needs, especially that the increases that took place in canola growth parameters and seed yield were significantly highly correlated with concurrent increases that took place in the uptake of NPK from soil and water.

Irrigation with treated wastewater has also stimulated the crop growth, seed yield and nutrient acquisition in different organs. Likewise, oil productivity increased due to irrigation with treated wastewater comparing to fresh water irrigated ones. The obtained results leads us to conclude that gamma ray has an accelerating effects on germination and cell division which need more research on genitival and cytological scale. Moreover, the treated wastewater could be safely used as an unconventional water resource since it contains remarkable amounts of essential nutrients in addition to its role in improvement of soil nutritional status especially those poor in nutrients budget like sandy soil. 


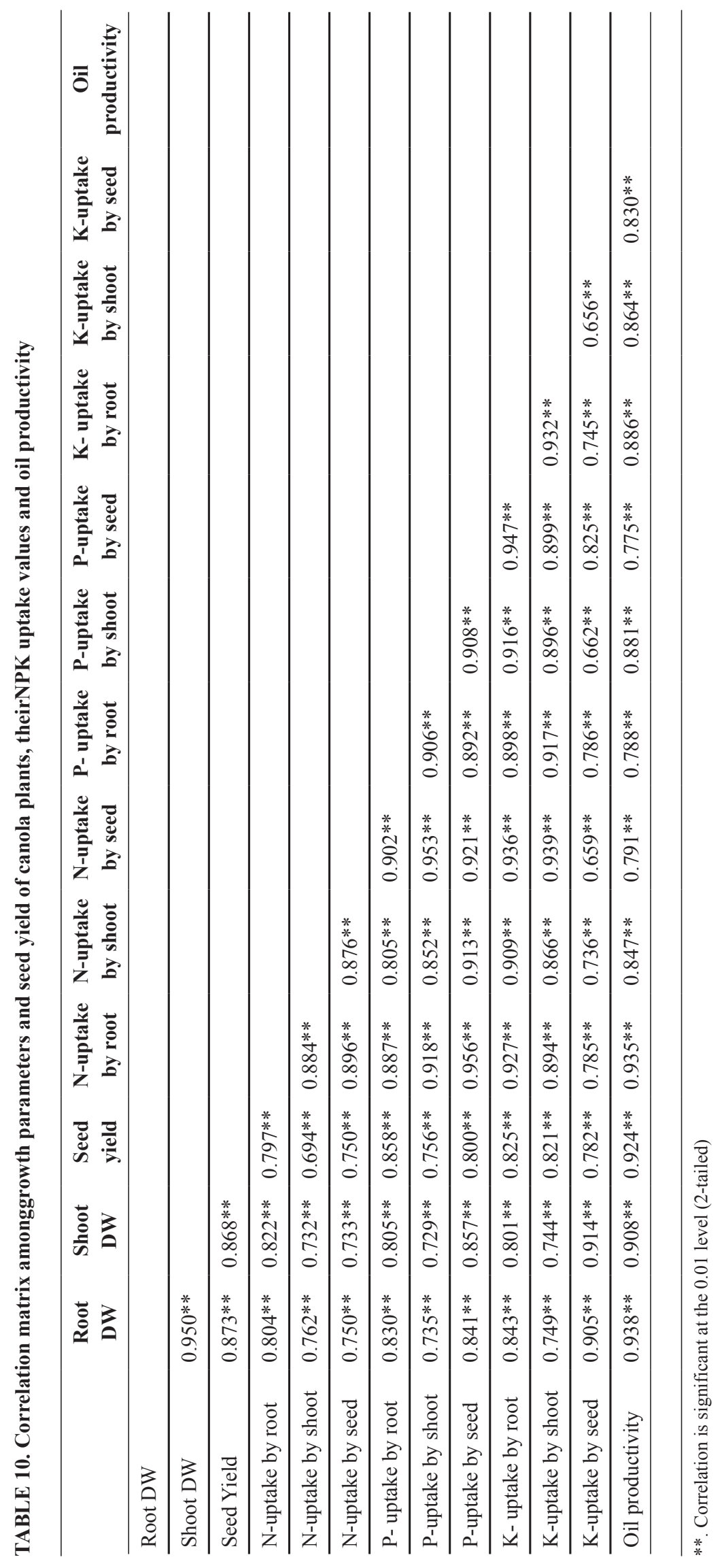

Env. Biodiv. Soil Security Vol. 4 (2020) 


\section{References}

Abbas, H., Abuzaid, A., Jahin, H. and D. Kasem (2020) Assessing the quality of untraditional water sources for irrigation purposes in Al-Qalubiya Governorate, Egypt. Egypt J Soil Sci, 60 (2), 143154. doi: 10.21608/ejss.2020.24569.1343

Abbas, H., Farid, I., Soliman, S., Galal, Y., Ismail, M.M., Kotb, E.A. and S.H. Moslhy (2015) Growth and some micronutrients uptake by castor bean irradiated with gamma ray and irrigated with wastewater under sandy soil condition. J. Soil Sci. Agric. Eng., Mansoura Univ. 6, 433-444. doi: 10.21608/jssae.2015.42187.

Abbas, M.H.H. and M. Bassouny (2018) Implications of long term irrigation with wastewater on the contents and retention kinetics of potentially toxic elements in Typic Torripsamment soils. Egypt J Soil Sci, 58 (3), 337-357. doi:10.21608/ ejss.2018.4232.1183.

AbdAllah, S., El-Ramady, H., El-Sherbeni, A., Anber, H., Keshk, E., Hamed, S. and H. Amine (2019) Monitoring water quality of some canals in Delta region, Egypt. Env. Biodiv. Soil Security3, 73-95. doi: 10.21608/jenvbs.2019.11428.1057.

Abdelhafez, A.A., Abbas, M.H.H., Attia, T.M.S., El Bably, W. and S.E. Mahrous (2018) Mineralization of organic carbon and nitrogen in semi-arid soils under organic and inorganic fertilization. Environ Technol Inno 9: 243-253. doi:10.1016/j. eti.2017.12.011.

Aboelsoud, H. and A. Ahmed (2020) Effect of biochar, vermicompost and polymer on wheat and maize productivity in sandy soils under drought stress. Env. Biodiv. Soil Security 4, 85-102. doi: 10.21608/ jenvbs.2020.29442.1095.

ADB (African Development Bank) (2009) Gabal El $\square$ Asfar Wastewater Treatment Plant Stage II Phase II Project; Country Egypt. Project Appraisal Report.

Ahmadi, M. and M.J. Bahrani (2009) Yield and yield components of rapeseed as influenced by water stress at different growth stages and nitrogen levels. Am-Euras J Agric Environ Sci 5 (6), 755761.

Akandeh, M., Soufbaf, M., Kocheili, F. and A. Rasekh(2017) Gamma irradiation on canola seeds affects herbivore-plant and host-parasitoid interactions. Neotrop Entomol 46, 256-263. doi:10.1007/s13744-016-0460-4.

Akbar E, Yaakob Z, Kamarudin S. and M. Ismail (2009) Characteristics and composition of
Jatropha curcas oil seed from Malaysia and its potential as biodiesel feedstock. Eur. J. scientific Res. 29, 396-403.

Ali, A. I., Kafkafi, U, Yamaguchi, I., Sugimoto, Y. and S. Inanaga (1998) Response of oilseed rape plant to low root temperature and nitrate:ammonium ratios. J Plant Nutr. 21, 1463- 1481. doi: 10.1080/01904169809365496.

Ali, M., Abdel-Hameed, A.H., Farid, I.M, Abbas, M.H.H. and H.H. Abbas (2016) To what extent can complimentary irrigation of wheat with wastewater, on soils along Belbais drain, affect soils? J. Soil Sci. and Agric Eng., Mansoura University.7(6), 409-416. doi: 10.21608/jssae.2016.39673.

Anwar M. M., Ali S. E. and E.H. Nasr (2015) Improving the nutritional value of canola seed bygamma irradiation. J. Rad. Res. Appl. Sci.,8, 328-333. doi:10.1016/j.jrras.2015.05.007.

Ariraman, M., Dhanavel, D., Seetharaman, N., Murugan, S. and R. Ramkumar (2018) Gamma radiation influence on growth, biochemical and yield characters of Cajanus Cajan (L.) Millsp. Journal of Plant Stress Physiology, 4, 38-40. doi:10.25081/jpsp.2018.v4.3504.

Bassouny, M. and M.H.H. Abbas (2020) Monitoring environmental pathways of trace elements in the northern east area of Egypt. Env. Biodiv. Soil Security. 4, 103-121, doi: 10.21608/ jenvbs.2020.29403.1094.

Bassouny, M., Abbas, M. and I. Mohamed (2020). Environmental risks associated with the leakage of untreated wastewater in industrial Areas. Egypt J Soil Sci 60 (2), 109-120. doi: 10.21608/ ejss.2019.18787.1319.

Blumenthal, U.J., A. Peasey, G. Ruiz-Palacios and D.D. Mara, (2000) Guidelines for wastewater reuse in agriculture and aquaculture: recommended revisions based on new research evidence". Final Report.Water and Environmental Health at London and Loughborough, England.

Bouchet A.-S., Laperche A., Bissuel-Belaygue Ch., Snowdon R., Nesi N., and A. Stahl (2016) Nitrogen use efficiency in rapeseed. A review. Agron. Sustain. Dev. 36 (38), 1-20.

Canola Council (2017) What is canola. Available at: https://www.canolacouncil.org/oil-and-meal/whatis-canola/ (Accessed May 12, 2019).

Carter, M. R. and E. G. Gregorich (2008) Soil sampling and methods of analysis. $2^{\text {nd }}$ ed. CRC, bocaratan, 


\section{FL. 1224 pp.}

Carter, M.R., Sanderson, J.B. and J.A. Macleod (2004) Influence of compost on the physical properties and organic matter fractions of a fine sandy loam through the cycle of a potato rotation. Can J. Soil Sci. 84, 211-218. doi: 10.1007/s13593-016-0371-0

Chai, R., Ye, X., Ma, C., Wang, Q., Tu, R., Zhang, L. and H. Gao(2019) Greenhouse gas emissions from synthetic nitrogen manufacture and fertilization for main upland crops in China. Carbon Balance Manage. 14, 20. doi: 10.1186/s13021-019-0133-9

Djaman, K., O’Neill, M., Owen, C., Smeal, D., West, M., Begay, D., Angadi, S.V., Koudahe, K., Allen, S. and K. Lombard (2018) Seed yield and water productivity of irrigated winter canola (Brassica napus L.) under semiarid climate and high elevation. Agronomy, 8 (6), 90. doi: 10.3390/ agronomy 8060090 .

Drechsel, P. and M. A. Hanjra (2018) Wastewater for fruit and wood production (Egypt) - Case Study. In Otoo, Miriam; Drechsel, Pay (Eds.). Resource recovery from waste: business models for energy, nutrient and water reuse in low- and middle-income countries. Oxon, UK: Routledge - Earthscan. pp.556-568. Available at:https://cgspace.cgiar. org/bitstream/handle/10568/93287/resource recovery_from_waste-556-568.pdf? sequence $=1$

Egiarte, G., Arbestian, C.M., Alonso, M. A., Rui'ZRomera E. and M. Pinto (2005) Effect of repeated applications of waste water sludge on the fate of $\mathrm{N}$ in soils under Monterey pine stands. For. Ecol. Manage. 216, 257-269. doi: 10.1016/j. foreco.2005.05.038.

El-Akhdar, I., Omara, A., Abdel-Rahman, M. (2018) Intergradation of different fertilizers for sustainable agriculture enhanced growth and yield of wheat (Triticum aestivum L.). Env. Biodiv. Soil Security, 2, 11-23. doi: 10.21608/jenvbs.2018.3479.1025.

Elcossy, S.A.E., Abbas, M.H.H., Farid, I.M., Beheiry, G.Gh., Abou Youssef,M.F., Abbas,H.H., Abdelhafez, A.A. and I. Mohamed (2020) Dynamics of soil organic carbon in Typic Torripsamment soils irrigated with raw effluent sewage water. Environ Sci Pollut Res, 1-11. doi: 10.1007/s11356-019-07526-4.

ElShazly, A.A., Abbas, M.H.H., Farid, I.M., Rizk, M., Abdelhafez, A.A., Abbas, H.H., Soliman, S.M., Abdel Sabour, M.F. and I. Mohamed (2019) Depthprofile distribution of $\mathrm{Cs}$ and its toxicity for canola plants grown on arid rainfed soils as affected by increasing K-inputs, Ecotoxicology Env. Biodiv. Soil Security Vol. 4 (2020) and Environmental Safety, 183, 109529, doi: 10.1016/j.ecoenv.2019.109529.

Elshony, M., Farid, I., Alkamar, F., Abbas, M. and H. Abbas (2019) Ameliorating a sandy soil using biochar and compost amendments and their implications as slow release fertilizers on plant growth. Egypt J Soil Sci, 59 (4), 305-322. doi: 10.21608/ejss.2019.12914.1276

Epstein, E.(1972) Mineral nutrition of plants: principles and perspectives. John Wiley and Sons Inc., London, UK.

Estefan, G.;Sommer, R. and J. Ryan (2013) Methods of soil, plant and water analysis: A manual for the West Asia and North Africa regions. International Center for Agricultural Research in the Dry Areas (ICARDA), 3 Ed.

FAOSTAT (2013) http://faostat3.fao.org/download/Q/ QC/E. Accessed 27 Nov 2015

Farid, I., Abbas, M., Bassouny, M., Gameel, A. and H. Abbas (2020a). Indirect impacts of irrigation with low quality water on the environmental safety. Egypt J Soil Sci. 60 (1), 1-15. doi: 10.21608/ ejss.2019.15434.1294

Farid, I., Hashem, A., Abd El-Aty, E., Abbas, M. and M. Ali (2020b) Integrated approaches towards ameliorating a saline sodic soil and increasing the dry weight of barley plants grown thereon. Env. Biodiv. Soil Security, 4, 31-46. doi: 10.21608/ jenvbs.2020.12912.1086.

Farid, I.M., Abbas, M.H.H. and A. El-Ghozoli (2018) Implications of humic, fulvic and $\mathrm{K}$-humate extracted from each of compost and biogas manure as well as their teas on faba bean plants grown on Typic Torripsamments and emissions of soil CO2. Egypt. J. Soil Sci. 58 (3), 275-298. doi: 10.21608/ ejss.2018.4232.1183.

Farid, I.M., Abbas, M.H.H., Beheiry, G.Gh.S. and S.A.E. Elcossy (2014). Implications of organic amendments and tillage of a sandy soil on its physical properties and $\mathrm{C}$-sequestration as well as its productivity of wheat and maize grown thereon. Egypt. J. Soil Sci, 54 (2), 177-194. doi: 10.21608/ ejss.2014.132.

Galal, Y., Soliman, S., Abbas, H.H., Farid, I., Kotb, E. and S. Moslhy (2018) Micro-nutritive elements in gamma-irradiated Jatropha influenced by wastewater irrigation. Asia Life Sciences, 27 (2), 425-440.

Galavi H. (2010) Effects of treated municipal 
wastewater on soil chemical properties and heavy metal uptake by sorghum (Sorghum Bicolor L.). Journal of Agricultural Science, 2 (3), 235-241. doi: $10.5539 /$ jas.v2n3p235.

Galavi M., Jalali, A. and M. Ramroodi (2010) Effects of treated municipal wastewater on soil chemical properties and heavy metal uptake by sorghum (Sorghum bicolor L.) J. Agric. Sci., 2 (3): 235 241. doi: $10.5539 /$ jas.v2n3p235.

Gan Y., Malhi S. S., Brandt S., Katepa-Mupondwa F. and C. Stevenson (2008) Nitrogen use efficiency and nitrogen uptake of juncea canola under diverse environments. Agronomy Journal, 100 (2), 285295. doi: 10.2134/agrojnl2007.0229.

Guo, L.B.; Sims, R.E.H.; and D.J. Horne (2002) Biomass production and nutrient cycling in Eucalyptus short rotation energy forests in New Zealand. I: biomass and nutrient accumulation. Bio resource Technol., 85, 273-283. doi: 10.1016/ S0960-8524(02)00118-9.

Hameeda, Gul, S., Bano, G., Manzoor, M., Chandio, T.A., Awan, A.A. and M.T. Moral (2019)Biochar and manure influences tomato fruit yield, heavy metal accumulation and concentration of soil nutrients under wastewater irrigation in arid climatic conditions, Cogent Food \& Agriculture, 5, 1 . doi: 10.1080/23311932.2019.1576406.

Hamideldin, N. and N.E. Eliwa (2015) Gamma irradiation effect on growth, physiological and molecular aspects of mustard plant. American Journal of Agricultural Science, 2 (4), 164-170.

Hassan, M.S. and S.H.M. Abd-El-Haleem (2014) Effectiveness of gamma rays to induce genetic variability to improve some agronomic traits of canola (Brassica napus L.). Asian J. Crop Sci. 6 (2), 123-132. doi:10.3923/ajcs.2014.123.132

Hozayn, M. and A.A. EL-Mahdy (2017) Evaluation of Yield and oil quality traits of some exotic canola (Brassica napus L.) genotypes grown under sandy soil in Egypt. Middle East Journal of Applied Sciences, 7 (4), 1148-1156

Ibrahim, Z.K., Abdel-Hameed, A.H., Farid, I.M., Abbas, M.H.H. and H.H. Abbas (2016) Implications of using Belbais drain water for irrigation of wheat in the North East region of Egypt. J. Soil Sci. and Agric Eng., Mansoura University., 7 (3),1-12. doi:10.21608/jssae.2016.39394.

Jackson G.D. (2000) Effects of nitrogen and sulphur on canola yield and nutrient uptake. Agron J92,
644-649. doi: 10.2134/agronj2000.924644x.

Javed, M.A., Siddiqui, M.A. Khan, M.K.R., Khatri, A. and I.A. Khan (2003) Development of high yielding mutants of Brassica campestris L. cv. Toria selection through gamma rays irradiation. Asian J. Plant Sci.2, 192-195. doi: 10.3923/ ajps.2003.192.195.

Kazemeini, S.A., Ghadiri, H., Karimian, N., KamgarHaghighi, A.A. and M. Kheradnam (2008) Interaction effects of nitrogen and organic matters on dryland wheat (Triticum aestivum L.) growth and yield. J. Sci Tech Agric Natu Resources, 14 (45), 461-473.

Kheir, A. and M. Kamara (2019) Effects of sugar beet factory lime, vinasse, and compost mixed with vinasse application on sandy soil properties and canola productivity. Journal of Soil Sciences and Agricultural Engineering, 10 (1), 69-77. doi: 10.21608/jssae.2019.36664.

Kiong, A., A. Ling, S. H. Pick, G. Lai and A. R. Harun (2008) Physiological responses of Orthosiphon stamineus plantlets to gamma irradiation. American Eurasian J. Sustainable Agric., 2, 135-149.

Kotb E. A., and A. A. Moursy (2018) Effect of humic acid, treated sewage effluent and radiation on canola growth and oil production. International Journal of Plant \& Soil Science. 24 (5): 1-8. doi: 10.9734/IJPSS/2018/43422

Kovacs, E. and A. Keresztes (2002) Effect of gamma and UV-B/C Radiation on plant cell. Micron, 33, 199-210. doi: 10.1016/S0968-4328(01)00012-9

Kumar, N., Rani, S., Kuamr, G.Rani, S., Kuamr, G., Kumari, S., Singh, I.S., Gautam, S. and B.K.Choudhary (2019) Physiological and biochemical responses of Makhana (Euryale ferox) to gamma irradiation. J. Biol Phys. 45, 1-12. doi:10.1007/s10867-018-9511-x

Kyari M.Z. (2008) Extraction and characterization of seed oils. Int. Agrophy. 22,139-142.

Larchevêque M., Ballini C., Korboulewsky N., and N. Montès (2006) The use of compost in afforestation of Mediterranean areas: effects on soil properties and young tree seedlings. Sci. Total Environ., 369:220-230. doi:10.1016/j.scitotenv.2006.04.017

Leal, R.M.P.,Herpin, U., Fonseca, A.F., Firme, L.P., Montes, C.R. and A.J. Melfi (2009) Sodicity and salinity in a Brazilian Oxisol cultivated with sugarcane irrigated with wastewater. Agric Water Manag, 96, 307-396. doi: 10.1016/j.

Env. Biodiv. Soil Security Vol. 4 (2020) 
agwat.2008.08.009.

Lewis, C.E. and C.W. Knight, (1987) Yield response of rapeseed to row spacing and rates of seeding and N- fertilization in interior Alaska. Can J Plant Sci67, 53-57. doi:10.4141/cjps87-006.

Lopez, A., Pollice, A., Lonigro, A., Masi, S., Palese, A.M., Cirelli, G.L., Toscano, A. and R. Passino (2006) Agricultural wastewater reuse in southern Italy. Desalination, 187, 323- 334. doi:10.1016/j. desal.2006.08.027.

Majeed, A., Muhammad, Z., Ullah, R., Ullah, Z., Ullah, R., Chaudhry, Z. and S. Siyar (2017) Effect of gamma irradiation on growth and post-harvest storage of vegetables. PSM Biological Research, 2 (1), 30-35.

Mohammad, M.J. and M. Ayadi (2004) Forage yield and nutrient uptake as influenced by secondary treated wastewater. J. Plant Nutr. 27, 351-364. doi: 10.1081/PLN-120027659

Mohammed, B. (2006) Design and performance evaluation of a wastewater treatment unit. AUJ.T., 9 (3), 193-198.

Muhammad N., Cheema, M. A., Wahid, M. A., Ahmad, N. and M. Zaman (2007) Effect of source and method of nitrogen fertilizer application on eed yield and quality of canola (Brassica napus L.). Pak. J. Agri. Sci. 44 (1), 74-78.

Rahimi, M. M. and A. Bahrani (2011) Effect of gamma irradiation on qualitative and quantitative characteristics of Brassica (Brassica napus L.). Middle-East J. Sci. Res., 8, 519-525.

Rathke, G.W., Christen, O. and W. Diepenbrock (2005) Effects of nitrogen source and rate on productivity and quality of winter oilseed rape (Brassica napusL.) grown in different crop rotations. Field Crops Res 94 (2-3), 103-113. doi:10.1016/j. fcr.2004.11.010.

Ravindran, B., Wong, J.W.C., Selvam, A. and G. Sekaran (2016) Influence of microbial diversity and plant growth hormones in compost and vermicompost from fermented tannery waste. Bioresour Technol. 217, 200-204. doi:10.1016/j. biortech.2016.03.032.

Rivero, C., Tchirenje L, Ma, Q. and G. Martinez (2004) Influence of compost on soil organic matter quality under tropical conditions. Geoderma, 123, 355361.doi: 10.1016/j.geoderma.2004.03.002.

Rose T. J., Rengel Z., Ma Q. and J. W. Bowden (2007)
Differential accumulation patterns of phosphorus and potassium by canola cultivars compared to wheat. J. Plant Nutr. Soil Sci. 170, 404-411. doi: 10.1002/jpln.200625163.

Rossato L., Lainé P. and A. Ourry (2001) Nitrogen storage and remobilization in Brassica napus L. during the growth cycle: nitrogen fluxes within the plant and changes in soluble protein patterns. $J$ Exp Bot. 52 (361): 1655-1663. doi:10.1093/ $\mathrm{jxb} / 52.361 .1655$

Rossato, L., Le Dantec, C., Laine, P. and Ourry, A. (2002) Nitrogen storage and remobilization in Brassica napus L. during the growth cycle: identification, characterization and immunolocalization of a putative taproot storage glycoprotein. J. Exp. Bot.53, 165-275. doi: 10.1093/jexbot/53.367.265 .

Rouhollahi, Z., Ebrahimi-Nik, M., Ebrahimi, S.H., Abbaspour-Fard, M.H., Zeynali, R. and M.R. Bayati (2020)Farm biogas plants, a sustainable waste to energy and bio-fertilizer opportunity for Iran, J Clean Prod, 253,119876,doi:10.1016/j. jclepro.2019.119876.

Sarwar, N., Saifullah, Malhi, S.S., Zia, M.H., Naeem, A., Bibi, S., and G. Farid (2010)Role of plant nutrients in minimizing cadmium accumulation by plant. J. Sci. Food Agric.90, 925-937. doi: 10.1002/jsfa.3916.

Sen, A., Ozturk, I., Yaycili, O. and S. Alikamanoglu (2017) Drought tolerance in irradiated wheat mutants studied by genetic and biochemical markers. J Plant Growth Regul. 36, 669-679. doi:10.1007/s00344-017-9668-8.

Shahzad A.N. and S. Ahmad (2019) Tools and Techniques for Nitrogen Management in Cereals. In: Hasanuzzaman M. (eds) Agronomic Crops. Springer, Singapore, pp 111-126.doi:10.1007/978981-32-9783-8_7.

Shareef, M., Gui, D., Zeng, F., Waqas, M., Ahmed, Z., Zhang, B., Iqbal, H. and J. Xue (2019) Nitrogen leaching, recovery efficiency, and cotton productivity assessments on desert-sandy soil under various application methods, Agric Water Manage223, 105716, doi:10.1016/j. agwat.2019.105716.

Siddiqui, M.A., Khan, I.A. and A. Khatri (2009) Induced quantitative variability by gamma rays and ethylmethanesulphonate alone and in combination in rapeseed (Brassica napus L.). Pak. J. Bot., 41P, 1189-1195. 
Šidlauskas, G. and P. Tarakanovas (2004) Factors affecting nitrogen concentration in spring oilseed rape (Brassica napus L.). Plant Soil Environ50 (5): 227-234.doi:10.17221/4026-PSE.

Sve $\square$ njak Z. and Z. Rengel (2006) Nitrogen utilization $\mathrm{e} \square$ ciency in canola cultivars at grain harvest. Plant and Soil, 283, 299-307. doi:10.1007/s11104-0060020-5.

Tang, Q., Ti, C., Xia, L., Xia, Y., Wei, Z. and X. Yan (2019) Ecosystem services of partial organic substitution for chemical fertilizer in a peri-urban zone in China. J Clean Prod. 224, 779-788. doi:10.1016/j.jclepro.2019.03.201.

USDA (2020) Oilseeds: World market and trade, United States Department of Agriculture, Foreign Agricultural Service. https://apps.fas.usda.gov/ psdonline/circulars/oilseeds.pdf (Accessed June 2020)

Vaillancourt, M., Chantigny, M., Pageau, D. and A. Vanasse (2018) Impact of a clover cover crop combined with organic or mineral fertilizer on yield and nitrogen uptake of canola. Canadian Journal of Plant Science, 98 (2), 332-344, doi: 10.1139/cjps-2017-0180.

Vaizo $\square$ ullar, H. E., Kara, Y., Kuru , A. and B. Parlak (2016)The Comparison of effects of gamma radiation of crude oil yield on some sunflower (Helianthus annuus) seeds. International Journal of Secondary Metabolite, 3 (1): 14-20. doi:10.21448/ijsm.240698.

Verma B.C., Pramanik P. and D. Bhaduri (2020) Organic Fertilizers for Sustainable Soil and Environmental Management. In: Meena R. (eds) Nutrient Dynamics for Sustainable Crop Production. Springer, Singapore, pp 289-313. doi:10.1007/978-981-13-8660-2_10.
Woźniak, E., Waszkowska, E., Zimny, T., Sowa, S. and T. Twardowski (2019) The rape seed potential in Poland and Germany in the context of production, legislation, and property rights. Front. Plant Sci., 10, 1423. doi:10.3389/fpls.2019.01423..

Xu, Y., Ma, Y., Cayuela, M.L., Sánchez-Monedero, M.A. and Q. Wang (2020) Compost biochemical quality mediates nitrogen leaching loss in a greenhouse soil under vegetable cultivation, Geoderma,358, 113984 doi:10.1016/j. geoderma.2019.113984.

Yassein, A.A.M. and A.A. Aly(2014) Effect of gamma irradiation on morphological, physiological and molecular traits of Brassica napus. Egypt. J. Genet. Cytol.43, 25-38. doi:10.21608/ejgc.2014.9931.

Yildiz, M.(2018) Seed dormancy as an obstacle in front of plant production. Trends in Horticulture, 1, 24-28. doi:10.24294/th.v1i3.799.

Yu, C., Huang, X., Chen, H., Yu, C., Huang, X., Chen, H., Godfray, H.C.J., Wright, J.S., Hall, J.W., Gong, P., Ni, S.Q., Qiao, S.C., Huang, G.R., Xiao, Y.C., Zhang, J., Zhao Feng, Z., Ju, X.T., Ciais, P., Stenseth, N.C., Hessen, D.O., Sun, Z.L., Yu, L. Cai, W.J.,Fu, H.H., Huang, X.M., Zhang, C., Liu, H.B. and J. Taylor (2019) Managing nitrogen to restore water quality in China. Nature, 567, 516-520. doi:10.1038/s41586-019-1001-1.

Zhang, X, Fang, Q, Zhang, T, Ma, W., Velthof, G.L., Hou, Y., Oenema, O. and F. Zhang (2020) Benefits and trade-offs of replacing synthetic fertilizers by animal manures in crop production in China: A meta-analysis. Glob Change Biol. 26, 888- 900. doi: $10.1111 /$ gcb.14826. 